\title{
Embryonic Stem Cell in the Therapy of Neurodegenerative Diseases
}

\author{
Xiaotang Fan'1, Yongping Tang², Kai Wang2, Xiang Cui², \\ Shiqi $\mathrm{Tao}^{2}$ and Haiwei $\mathrm{Xu}^{3,4}$ \\ ${ }^{1}$ Department of Histology and Embryology, Third Military Medical University, Chongqing, \\ ${ }^{2}$ Department of Physiology, Third Military Medical University, Chongqing, \\ ${ }^{3}$ Southwest Hospital, Southwest Eye Hospital, Third Military Medical University, Chongqing, \\ ${ }^{4}$ Center for Nuclear Receptors and Cell Signaling, University of Houston, Houston, \\ 1,2,3.R.China \\ 4 USA
}

\section{Introduction}

Neurodegenerative diseases comprise a heterogeneous spectrum of neural disorders in human and affect millions of individuals worldwide. Although these neurodegenerative diseases arise from unknown reasons, their common typical histological feature is the occurrence of disease-related cell death in specific regional subpopulations of neurons such as the loss of dopaminergic (DA) neurons in the substantia nigra in the Parkinson's disease (PD) and loss of medium spiny neurons in the striatum in the Huntington disease(HD), they can also possibly affect the diversity neurons and glial cells such as the multiple selective neurons loss throughout the basal forebrain, amygdala, hippocampus, and cortical area in Alzheimer`s disease (AD) and dysfunction of supportive glial cells around somatic motor neurons in amyotrophic lateral sclerosis (ALS) (Srivastava et al., 2008). Adult central nervous system (CNS), different from many other tissues, cannot regenerate and loss of mature neural cells is thought to be irreversible. As the increasing of life expectancy in this aging society, the neurodegenerative diseases usually cause morbidity and mortality as well as increased social and economic burdens of patients and caregivers. Current drugs used for treating neurodegenerative diseases provide only limited benefits by alleviating certain symptoms, but cannot halt progress of these diseases. In addition, their chronic use is often associated with serious side effects (Mangialasche et al., 2010; Kim et al.,2007). Fetal tissue and cell transplantation in animal models and patients has pointed to be an alternative treatment for these diseases, which can provide neurons to replace lost or degenerated neurons, but due to the lack of donor tissues, it will be limited in clinical trials. Promising donor cells need to be developed for treating these diseases (Schwarz \& Schwarz, 2010;Freed et al., 2001; Nishimura et al., 2003).

Rapid advances in stem cell biology have opened an alternative, fascinating perspective treatment for neurodegenerative disease. Stem cells as donor cells used in neurodegenerative disease include three different sources: neural stem cells (NSCs) from the embryonic or adult brain, stem cells in other tissues, or embryonic stem cells (ESCs) from the fertilized egg (Shihabuddin \& Aubert., 2010). 
Adult progenitor cells from bone marrow or cord blood have been shown to generate neurons both in vitro and in vivo studies, although the number of neurons was very low (Chua et al., 2009; Greschat et al., 2008; Bicknese et al., 2002; Song \& Sanchez-Romos.,2008). The results indicated that stem cells in these tissues would be promising candidates for cellreplacement therapy due to their accessibility. However, some experiments cannot replicate these results, no new neurons production has been observed in these studies, the neural differentiation of these stem cells supposed to be artifacts such as occasional cell fusion with host neurons appeared in original observations (Rizvanov et al., 2008; Luo et al.,2009). Trans-differentiation of adult progenitor cells from bone marrow or cord blood needs more evidence to confirm before they used as donor cells in treating neurodegenerative disease.

NSCs from the embryonic brain have the ability to renew themselves continuously and possess pluripotent ability to differentiate into three major CNS cell types, neurons, astrocytes, and oligodendrocytes (Reubinoff et al., 2001). Under certain conditions, NSCs can also be induced to differentiate into typical neurons such as dopaminergical neurons. When transplanted into animal models, embryonic brain-derived NSCs can survive and even replace the lost cells caused by brain injury(Goings et al., 2004; Arvidsson et al., 2002). But it has indicated that human or rat fetal NSCs or neural precursors(NPs) appeared to be more limited in terms of their differentiation potential, difficult to maintain long-term expansion without decline in proliferative and neurogenic capacity (Cao et al., 2002). The accessibility to get human fetal NPs also needs to be concerned. In the mammalian adult brain including human, NSCs isolated from subventricular zone (SVZ) and hippocampus dentate gyrus(DG) have the ability of self-renewing and pluripotency similar to those isolated from embryonic brain (Vandenbosch et al., 2009; Jin \& Galvan, 2007; Consiglio et al., 2004; Tropepe, 2007; Okano, 2002). This prompts very promising new strategy to replace lost neurons through auto-transplantation, however, it is still stopped due to their uncertainty in long-term expansion and reliable differentiation, which will be partially determined by the stage of development when NSCs were isolated (Soares \& Sotelo, 2004). Meanwhile, to increase proliferation rate and decrease the physiological senescence in culture, the immortalized cell lines of human NSCs usually were introduced with oncogenes which usually resulted in the high risk of transformation (De Filippis et al., 2008).

ESCs derived from the inner cell mass of blastocysts give rise to various organs and tissues. ESCs are able to differentiate into all cell types of ectoderm, endoderm and mesoderm (Evans \& Kaufman, 1981; Thomson et al., 1998). It has been demonstrated that in vitro ESCs can differentiate effectively into NPCs which further differentiate into neurons and glia (Tang et al., 2008). The self-renewing and totipotent ability of ESCs have made it an intriguing and attractive donor source for cell-based therapies in neurodegenerative diseases and brain injury (Reubinoff et al., 2001). Human embryonic stem cells (hESCs) usually isolated from early human embryos which makes it encounter ethical risks(Dickens \& Cook, 2007; Baylis, 2008). However, in 2006, researchers identified conditions of allowing some specialized adult somatic cells to be "reprogrammed" genetically to assume a stem cell-like state. This new type of stem cell, called induced pluripotent stem cells (iPSCs), make it possible to obtain human ESCs without destroying the human embryos (Takahashi \& Yamanaka, 2006). On the contrary, some studies have suggested that the iPSCs might not be an alternative to ESCs, they have different pluripotent ability to turn into different types of tissues (Schwarz \& Schwarz,2010). Moreover, the first-ever hESCs-based investigational new drug (IND) application to treat spinal cord injury has been approved by the U.S. Food 
and Drug Administration (FDA) in January 2009. It seemed that hESCs could be expected as a potential future cell source for cell therapy in neurodegenerative disease.

$\mathrm{AD}$ and PD are the most prevalent kinds of neurodegenerative diseases in ageing people. Although not so prevalent, HD and ALS are devasting motor neuron degenerative diseases, the patients usually died of this disease shortly after diagnosis (Roze et al., 2010; Perry et al., 2010).These neurodegenerative diseases share many important commonalities, characterized by neuron loss as structural feature. Meanwhile, a different spectrum of cell types is affected in these diseases. Therefore, different types of neurons are required for replacement (Srivastava et al., 2008). When stem cell transplantation used in these diseases, the strategies will vary according to the primary defect of a disease. As above-mentioned, ESCs are promising cell source for cell therapy in neurodegenerative disease, recent progress of ESCs-based therapies in these diseases is discussed below.

\section{Embryonic stem cell biology}

\subsection{Cellular and molecular characteristics of embryonic stem cell}

ESCs were independently first derived from mouse embryos by Martin Evans and Mattew kaufman in 1981 (Evans \& Kaufman, 1981). This is also the first time to reveal a new technique for culturing the mouse embryos in the uterus to allow for an increase in cell number, which has been further confirmed by Martin (Martin et al., 1987). In 1998, James Thomson firstly developed a technique to isolate and grow hESCs in cell culture (Thomson et al., 1998). Later, ESCs have been isolated from other species, including swine, simian, monkeys and human blastocysts, but only three species of mammals have yielded long-term cultures of self-renewing ESCs namely mice, monkeys and humans (Ohtsuka \& Dalton, 2008).

Both mouse and human ESCs have the properties of self-renewal and the potential to be committed and differentiated in vitro into all three germ layers-namely, ectoderm, endoderm, and mesoderm (Murry \& Keller, 2008). Both stem cell populations express the characteristic markers of undifferentiated cells, including Oct-4(octamer binding transcription factor-4), nanog, Sox-2(SRY- related HMG box 2) and utf-1, together with the lack of differentiation markers (Sauerzweig et al., 2009). They also express stage-specific embryonic antigen-3 and -4 (SSEA-3 and -4), tumor-rejection antigen-1-60 and -1-81, and high levels of telomerase activity (Murry \& Keller, 2008). ESCs cultures from mouse and human are similar in that they grow as colonies of tightly packed cells on inactivated murine embryonic fibroblast(MEF) feeders or in conditioned medium(CM) derived from such MEFs (Li et al., 2005). The mechanisms by which ESCs from different species maintain self-renewal and pluripotency are still not yet fully understood. It seemed that they have different mechanisms. Maintenance of mouse ESCs pluripotency in vitro is achieved by coculture on irradiated mouse fibroblasts or on gelatinized dishes with a differentiation inhibitory factor called leukemia inhibitory factor(LIF) (Cheng et al., 2003). In addition to LIF, bone morphogenetic protein $4(\mathrm{BMP} 4)$ and the secreted wnt proteins may also contribute to maintain ESCs pluripotency (Hiller et al., 2010). Other factors such as Sox2, FoxD3 (forkhead box D3) and Nanog can also maintain self-renewal of mouse ESCs.

Human ESCs pluripotency is regulated by a combination of extrinsic and intrinsic factors. Unlike mouse, extrinsic factors such as fibroblast growth factor(FGF) signaling and a balance between transforming growth factor- $\beta$ (TGF- $\beta$ )/activin and BMP signaling are central to the self-renewal of human ESCs (Xu et al., 2008). Intrinsic factors regulating 
pluripotency in human ESCs include a battery of transcription factors such as Oct4, SOX2, SRY (sex determining region-Y), Box-2 and Nanog (Liber et al., 2010).

\subsection{Embryonic stem cell based transplantation therapy}

ESCs possess several characteristics that make them promising donor cells for transplantation therapy in neurodegenerative diseases. When ESCs transplanted into animal models which mimic the typical aspects of neurodegenerative diseases, structural and functional recovery were also confirmed, although the efficiency were variable. The safety of ESCs transplantation is always an important problem to be considered carefully. It has been demonstrated by many studies that ESCs transplantation in the brain tended to form teratomas, which is an unacceptable adverse effect for cell transplantation therapy (Wesselschmidt et al., 2007). The main strategy to enhance the safety of ESCs for potential clinical use is to differentiate the ESCs into neural precursors cells(NPCs) with different commitment or mature neurons before transplantation (Shihabuddin \& Aubert, 2010). Thus, there are two principally different ways of using ESCs for grafting in neurodegenerative disease. First, ESCs are pre-differentiated in vitro to specific neurons such as DA neurons prior to transplantation in PD, thus, ESCs could become an almost unlimited source for the generation of specific neurons. The cell preparations could be standardized and qualitycontrolled with respect to viability and purity (Shihabuddin \& Aubert, 2010). The second alternative is that the ESCs are induced effectively into NPCs with different commitment, which then differentiates in vivo to specific neurons after being implemented into specific brain regions.

In vivo studies have demonstrated that transplantation of NPCs and neurons derived from ESCs are safe and carry no risk of tumor formation, the immunogenic reactivity is also relatively low (Cai \& Rao, 2007). We argue that long-term survival of new, functionally integrated neurons is the main goal to achieve maximum symptomatic relief through stem cell therapy. More evidence has confirmed that the observed functional recovery after ESCsderived NPCs and neurons were transplanted into animal models of neurodegeneration and injury appeared to be related to structural reorganization including synapse formation and functional integration (Moghadam et al., 2009; Tang et al., 2008). In the developing brain, grafted ESCs-derived neurons developed functional properties of postmitotic neurons adopted excitatory and inhibitory neurotransmitter phenotypes and formed synapse with host cells (Wernig et al., 2004). In the injured brain regions, grafted ES cell-derived precursors differentiated into neurons and exhibited voltage-gated inward and outward currents, expressed functional neurotransmitter receptors, and formed synaptic contacts (Wernig et al., 2008). Thus, NPCs with different commitment and neurons from ESCs have been prospective in CNS repair.

\subsection{NPCs and neurons differentiation potential of embryonic stem cell 2.3.1 NPCs induction from embryonic stem cell}

NPCs derived from ESCs can be expanded in large numbers for significant periods of time and their plasticity potential allows them to differentiate according to the environmental cues of host brain (Sakaguchi et al., 2005; Takagi et al.,2005). Getting the NPCs of high purity from ESCs is an important step in transplantation research. Evidences from mouse ESCs in vitro culture studies have indicated that NPCs can be generated from ESCs and can be expanded and differentiated efficiently to neurons and glial cells by serum-free culture 
(Okabe et al., 1996). The protocol of neural differentiation of ESCs usually involved the formation of embryoid bodies(EBs) and the subsequent culture of the attached EBs in a selective, serum-free medium to eliminate non-neural cells. Culture of the EBs-derived cell pool in this serum-free, selective medium results in a dramatic decrease in cell number, as the majority of the cells do not survive under these culture conditions (Lendahl et al., 1990). Insulin-Transferrin-Selenium-Fibronectin (ITSF) and N2 serum-free medium have been demonstrated to support the selective growth of NPCs (Xu et al., 2004). Considering fibronectin increases the neural differentiation of ESCs, offers a tool for growing NPCs as a monolayer without impairing their differentiation potential and to generate specific differentiated progeny for cell transplantation, we modified the culture medium by adding fibronectin $(5 \mu \mathrm{g} / \mathrm{ml})$ in the N2 serum-free selective culture and found that the number of surviving cells was increased significantly when EBs were plated. After ESCs were cultured in this modified NPC-selective medium for 5 days, more than $93 \%$ cells were nestin-positive. (Xu et al., 2005). The percentage of nestin-positive cells was increased compared with the classic method of Okabe, in which the ITSF media was used and the percentage of nestinpositive cells was $84.1 \%$ (Okabe et al.,1996).

The feasibility of hESCs based cell transplantation in the CNS depends on the generation of human neural precursors (hNPs) in vitro. There are several methods for induction of hESCs to hNPs, usually rely on EBs formation, stromal feeder co-culture or selective survival conditions similar to murine ESCs. Recently, rapid and simple generation of proliferating hNPs from feeder free cultures of undifferentiated hESCs has been described. In this protocol, hNPs typically expressed neuroectodermal and progenitor markers are derived by seeding undifferentiated hESCs on adherent surfaces of laminin or gelatine with normal hESCs culturing medium and with the addition of bFGF (Benzing et al., 2006). The process of induction of hESCs to hNPs is quite similar to neural induction during embryogenesis. Several lines of evidence demonstrate a crucial role for BMP inhibitors including chordin, follistatin and noggin as neural inducing factors during neural differentiation of hESCs. It seems that the synergistic action of two BMP inhibitors, Noggin and SB431542, are sufficient to induce rapid and complete neural conversion of $>80 \%$ of hESCs under adherent culture conditions (Chambers et al., 2009; Pera et al., 2004). In another study, hNPs from hESCs produced with a feeder-free system, different media components were compared for the efficiency of hNPs generation. Media with N2 produced higher number of hNPs without proliferation, media with non-essential amino acids and knock-out serum replacement produced fewer number of hNPs with proliferation, and by five passages the culture consisted of $>97 \%$ hNPs. This resulted in an efficient, robust, repeatable differentiation system suitable for generating large populations of hNP cells from hESCs (Dhara et al., 2008).

\subsubsection{Neurons differentiation from embryonic stem cell}

It has been demonstrated that relatively pure of neurons, astrocytes, and oligodendrocytes which constitute three major neural cell types of the CNS, can be generated from ESCs under appropriate culture conditions (Zhang \&Zhang, 2010). Obviously, neuron production from ESCs in vitro is similar to neural induction occurred in embryo development, and many important factors or signaling pathways have been determined such as $\beta$-catenin and wnt signaling pathway (Cajánek et al., 2009). In vitro study has indicated that ESCs transfected with noggin or exposure to noggin-conditioned medium will enhance neuronal 
differentiation, while addition of BMP4 strikingly inhibited neuronal differentiation (Zhang et al., 2010). Human ES cells can be directed to neurons when exposure to retinoic acid and mitogen FGF-2, although selected using cell-sorting methods, the cell population obtained after application of this differentiation strategy is still relatively heterogeneous (Guan et al., 2001).

Moreover, protocols have been developed for the generation of different subtypes of neurons including the sequential combination of regulators. Especially, fetal tissue transplantation trials provided important clues for factors inducing typical neurons differentiation. For instance, midbrain DA neurons have been generated in the EBs system by overexpression in the cells of the transcription factor nuclear-receptor-related factor1 (Nurr1), and the addition to the cultures of SHH and FGF8 (Lee et al., 2000). Using the coculture approach together with the appropriate signaling molecules and selection steps, successfully generated cells that display many of the characteristics of motor neurons from hESCs (Wichterle \& Peljto, 2008 ).

\section{ESCs therapy for neurodegenerative diseases}

\subsection{Alzheimer's disease}

$\mathrm{AD}$ is a most prevalent kind of dementia and clinically defined as progressive deficits of cognition, memory and the ability to live on oneself (Marlatt \& Lucassen, 2010). It was diagnosed mostly in people over 65 years of age although the less-prevalent early-onset AD can occur much earlier (Brookmeyer et al., 1998; Marlatt \& Lucassen, 2010). In 2006, there were 26.6 million AD sufferers worldwide, the number is predicted to be 1 in 85 people globally by 2050 (Brookmeyer et al., 2007). The neuropathology of AD is characterized by deposition of insoluble $\beta$-amyloid peptides/senile plaques, the intracellular neurofibrillary tangles(NFTs) and the diversity selected neurons loss throughout the basal forebrain, amygdala, hippocampus, and cortical area (Kim \& de Vellis, 2009; Whitehouse et al., 1981).

The etiology and progression of $\mathrm{AD}$ are not well understood. It is multi-factorial and heterogeneous, which is related with the age, sex, the genotype for apolipoprotein E (Apo E), and the sequential proteolytic processing of the amyloid precursor protein(APP) (Blennow et al.,2006). Current treatment strategies for AD include targeting cholinergic and glutamatergic neurotransmission, moderating the $\gamma$-secretase to generate non-toxic $\beta$ amyloid(A $\beta$ ) fragment and delivering NGF into brain which can alleviate symptoms, while these treatments cannot delay or halt the loss and degeneration of neurons in AD brains (van Marum, 2008). Moreover, it has been recognized that the irreversible decline of cognitive functions was related to neuron loss in the forebrain cholinergic projection system: especially in nucleus basalis of Meynert(nbM) where a massive extracellular deposition of $\mathrm{A} \beta$ protein occurs in the later stages of the disease (Boncristiano et al.; 2002; Oliveira \& Hodges, 2005).

The development of stem cell biology make it a promising treat approach for AD sufferers to restore the lost neurons. Currently stem cell-based therapy for AD is confined to preclinical studies on animal models (Sugaya \& Merchant, 2008). The effectiveness of several stem cells transplantation has been explored and the results are quite similar, sustaining an improvement of the mouse's or rat's cognitive functions and a general improvement with reference to AD pathogenesis hallmarks (Shihabuddin \& Aubert, 2010). When cholinergicrich tissue and peripheral cholinergic neurons were transplanted into an AD rat model with $\mathrm{nbM}$ lesions, memory improvement which indicated a partial neuronal rescue has been 
found in these animal models. However, it is difficult to get enough donor cells, no clinical trials in AD patients have been initiated with this method (Fine et al., 1985).

When ESCs as donor cells transplanted directly in AD animal model, it usually resulted in teratomas formation instead of producing neurons (Ringdén et al., 2003; Wang et al., 2006). However, ESCs-derived neurospheres, NPCs and neurons transplantation were evaluated in animal models and proved to be safe. Wang and colleagues has demonstrated that ESCsderived neurospheres transplanted into frontal cortex of Meynert nucleus lesion mouse model survived and produced many ChAT-positive neurons and a few serotonin-positive neurons in and around the grafts, and the improved working memory was also observed after transplantation (Wang et al., 2006). Moghadam and colleagues further implanted primed and unprimed mouse ESCs-derived NPCs into the unilateral nbM of rat model of $\mathrm{AD}$, Morris water maze and spatial probe test revealed a significant behavioral improvement in memory deficits following cells transplantation. Immunohistochemical analysis revealed that the majority (approximately 70\%) of the NPCs retained neuronal phenotype and approximately $40 \%$ of them had a cholinergic cell phenotype following transplantation (Moghadam et al., 2009). These studies suggest transplantation of mouse ESCs-derived NPCs and/or following commitment to a cholinergic cell phenotype can promote behavioral recovery in a rodent model of AD.

Consistent with above studies, we also confirmed that therapy effects of NPCs derived from ESCs following transplantation into the rat model of AD. In our studies, we used a derivative of the MESPU35 ES cell line that constitutively expresses enhanced green fluorescent protein(EGFP), thus allowing us to distinguish between transplanted and host cells. Firstly, we investigated the in vivo characteristics of NPCs after differentiation from the ESCs following transplantation into the $\mathrm{A} \beta$-injured dorsal hippocampus of rats. $\mathrm{A} \beta$-injured rats receiving ESCs derived NPCs grafts revealed amelioration of the memory impairment at least 16 weeks. Obviously, only live transplanted NPCs can bring about functional recovery, the survival of transplanted NPCs in the hippocampus declined with time, while the differentiation rate was increased. We found that $9.41 \%$ of grafted EGFP-expressing NPCs differentiated into NF-200 positive cells and $11.31 \%$ into GFAP positive cells respectively 4 weeks after transplantation. These ratios gradually increased to $40.25 \%$ and $19.35 \%$ by $16 \mathrm{~W}$. Meanwhile, we also noticed that most of the NPCs remained in a cluster and possessed a round morphology that kept unchanged over the experimental period, some NPCs were found dorsally along the needle tract, a few NPCs had migrated tangentially along the granule cell layer (GCL) in the DG region. Of particular note is the fact that these migrating cells within the hippocampus were clearly differentiating along a neuronal lineage indicating that the microenvironment can support neuronal differentiation, and should be, therefore, also suitable for transplanted NPCs. This may overcome the problem of low neuronal differentiation rate of the transplanted NSCs in the host brain (Tang et al., 2008). On the other hand, DG of the hippocampus is a few region neurogenesis occurred in the adult mammals including primates and humans, and the newborn granule cells contribute to processing of learning and memory. Using APPswe/PS1DeltaE9 mouse model of AD, we have demonstrated that the cell proliferation in the DG of AD was declined significantly (Li et al., 2008), meanwhile increased hippocampus neurogenesis contributes to memory function recovery has been reported in many studies (Duan et al., 2008; Mohapel et al., 2006). Therefore, NPCs transplantation in the DG of hippocampus, maybe a new promising therapeutic strategy of AD compared with dorsal hippocampus transplantation. 
To confirm this hypothesis, in our recent study, injection of a toxic fragment of $A \beta_{1-40}$ into the upper leaf of DG was used to make an in vivo, AD-like rat model. Selective loss of granular neurons mainly observed in the upper leaf of the DG near the injection site, which is consistent with the results of Reyes(Reyes et al., 2004). Similar to our previous finding that NPCs derived from ESCs grafted into dorsal hippocampus, the spatial learning and memory were improved in animals with NPCs transplantation into DG of the hippocampus(Tang et

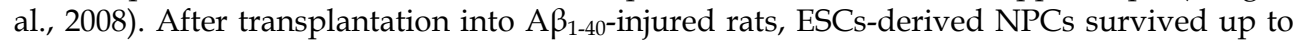
12 weeks and migrated along the upper leaf of the DG, where granular cells were degenerated and lost. We further demonstrated that grafted cells differentiated well in the DG of the hippocampus as seen by checking neuronal and glial markers after transplantation. In addition, it showed that these incorporated donor neurons exhibited a broad spectrum of neuronal morphologies ranging from simple bipolar to complex multipolar phenotypes. Meanwhile, the abundant labeled glutamatergic and GABAergic neurons were seen in 8 and 12 weeks after grafting, donor neurons also expressed proteins essential for synaptic transmission, including the major subunits of ionotropic glutamate and GABA receptors (NR1, GluR1) and $\mathrm{GABA}_{\mathrm{A}}$ receptor $\beta$-chain, respectively(Li et al., 2010).

Numerous reports point out that the therapeutic effect mediated by the transplanted cells in various neurological disorders depends on the functional integration of transplanted cells into brain circuits upon in vivo differentiation into mature cells (Maroof et al., 2010; Aldskogius et al., 2009; Reubinoff et al., 2001). To testify the possibility of integration of ESCs derived neurons in the hippocampus of AD rats, the synapse formation between donor neurons and host neurons were demonstrated by PSD-95-positive puncta and synaptophysin positive puncta. The density of PSD-95 and synaptophysin positive puncta showed higher level at 12 weeks post transplantation compared with 8 weeks. This was further confirmed using Qtracker ${ }^{\circledR}$ Cell Labeling technique, that is, the engrafted cells were pre-labeled by Quantum dots (QDs) before cell transplantation which makes them visible under bright field, fluorescence field and electron microscopy(EM), they formed typical ultrastructure of post-synaptic or pre-synaptic connections with host neurons following transplantation when observed under EM. Our study directly showed that synapse formation between host and donor neurons, which provided morphological evidences for the reconstruction of damaged hippocampal neuronal networks in AD by cell transplantation ( $\mathrm{Li}$ et al., 2010). Many studies have demonstrated that the grafted cells effectively signal to the host and vice versa by electrophysiological demonstration, for instance, paired recordings as the most stringent criteria for functional integration and crosstalk between host and graft. C-fos as another good candidate for the initial steps of learning inducing long term synaptic plasticity, we found that, after behavioral training, there was an increase in the percentage of co-localization of Fos and EGFP in hippocampal DG of $A \beta_{1-40}$-injured rats compared to that in rats with stationary stimulation. This indicates an involvement of the engrafted neurons in the circuitries contributing to learning and memory (Li et al., 2010).

Therefore, the effectiveness of these ESCs transplantation is quite similar, sustaining an improvement of the animal's cognitive functions and promising reconstruction of structural and function (Sugaya et al., 2007; Sugaya et al., 2006; Sugaya, 2005; Marlatt \& Lucassen, 2010; Taupin, 2009). Since the neuropathological changes of AD is too widespread throughout the brain, it seems very difficult to decide the place for grafting and the dosage of cells, this makes the cell transplant therapy more difficult than that of single brain site 
impact diseases like PD and HD (Imitola, 2007). Based on our study, DG is a promising site for grafting NPCs derived from ESCs, the long term recovery evaluation at structure and function level needs to be explored in the future.

As $A \beta$ deposition is a hallmark of $A D$, the effect of $A \beta$ on the survival, migration and differentiation of grafted cells is the major factor deserves to be taken into consideration. Sugaya reported that human NSCs transplanted into the brain of APP transgenic mouse exhibited less neurogenesis and active gliosis around the plaque like formations, while using a well-defined in vitro culture differentiation model of NSCs, it found that APP is necessary for the migration and differentiation of NSCs, suggest APP level can regulate NSCs biology, the changes of APP metabolism in AD will cause the deficiency of grafted stem cells (Sugaya \& Brannen, 2001; Sugaya et al., 2006). It reported recently that the APP is expressed by human ESCs, and the differential processing of APP regulates the proliferation and differentiation of ESCs. The exogenously added soluble and fibrillar APP significantly reduces the proliferation of ESCs and increases the NPCs differentiation (Porayette et al., 2009). It was reported that human NSCs exposed to high concentrations of secreted amyloid-precursor protein (sAPP) in vitro differentiated into mainly astrocytes, suggesting that pathological alterations in APP processing in AD may prevent neuronal differentiation of NSCs (Marutle et al., 2007; Kwak et al., 2010). Thus, successful cell transplantation therapy for $\mathrm{AD}$ may require regulating APP expression to favorable levels to enhance neuronal differentiation of NSCs at the same time.

\subsection{Parkinson's disease}

PD is the second most common neurodegenerative disorder, clinically characterized initially by muscle rigidity, resting tremor, and slowing of movement. Over time, patients sustain a loss of mobility and dysautonomia, dystonic cramps and dementia (Jankovic, 2008). The common pathological features in PD patients are degeneration of DA neurons in the midbrain and diminished dopamine in the striatum, which normally receives substantia nigra (SN) dopamine inputs (Kish et al., 1988; Agid, 1991). The vast majority of cases are sporadic, and some of these are caused by mutations in a-synuclein, parkin, UCHL1, DJ1, PINK1, and LRRK2, with a Mendelian pattern of inheritance (Hardy, 2003). All current PD therapies focus on restoring the dopamine levels by either the oral administration of the dopamine precursor levodopa (L-DOPA), which supplements the low level of endogenous dopamine, or inhibition of the breakdown of endogenous dopamine by treatment with the monoamine oxidase type B (MAO-B) inhibitor, selegiline (Hardy, 2003). Dopamine agonists are also used to directly stimulate the dopamine receptors. Unfortunately, these therapies are all symptomatic treatments, they do not prevent the progress of the DA neuronal degeneration and, more importantly, are not capable of curing PD. In the later stages of this treatment, L-DOPA becomes ineffective or, even worse, causes severe side effects, such as the development of dyskinesias (Fahn et al., 2004; Lang \& Lozano, 1998 a,b). Surgical treatment by deep brain stimulation is practiced to further modify dyskinesias. Although advanced, this treatment does not stop the progression of the disease either, therefore there is a great need to develop new regenerative therapeutic strategies that directly target the degenerating DA neurons or their innervation areas (Walter \& Vitek, 2004).

Cell transplantation from fetal tissues has offered some success in the treatment of Parkinson's disorder, but is limited by the difficulty of obtaining the tissues for transplantation (Lindval et al., 1990; Olanow et al., 1996; Kordower et al., 1997; Dunnett \& Björklund, 1999). Extensive in vivo animal studies have shown that fetal ventral 
mesencephalic (VM) grafted into rats striatum of PD models produced marked recovery from amphetamine induced rotational asymmetry. The grafts could survive in host striatum, restore the damaged nigrastriatal pathway and release dopamine (Perlow et al., 1979; Freund et al., 1985). Based on these experimental data, clinical trials with transplantation of fetal VM into patients were initiated in 1987, and transplantation efficacy has been shown in open-label trials without post-operative complications. Fetal VM transplantation seems to be promising in treating PD, and the clinical benefits have been reported in early clinical trials (Lindvall et al., 1989). However, outcomes following transplantation of fetal VM in PD patients were variable. In the best cases, DA neurons survived, released dopamine and the major clinical improvement could last for up to 6 to 12 years post-surgery (Piccini et al., 1999). On the other hand, two NIH-sponsored, doubleblind clinical trials had found that some patients failed to show behavioral recoveries observed in the previous open-label trials and suffered graft-induced dyskinesias, probably caused by the grafts' excessive and uncontrolled proliferation and release of dopamine (Björklund, 2005; Winkler et al., 2005). Although the disparity in the outcome from clinical trials is not clear, probably is related to many factors, including the age of the donor tissue, the severity and stage of the disease and the difference in immunosuppressant treatment in patients. The variable results from clinical trials, together with the lack of donor tissues and standardization of protocols have led to re-evaluation of the use of such tissue for further transplantation into humans. In this regard, human ESCs could be a potential future alternative cell source for cell -replacement therapy for PD.

It is necessary for transplanted cells to synthesize dopamine and to control release, reuptake, and metabolizing dopamine, as the original DA neurons to treat PD. There are two principal different ways of using ESCs pre-differentiated into DA neurons and stem or progenitor cells with different commitment transplanted into the striatum or SN. Mouse ESCs transplanted into adult mouse brain and kidney capsule developed large numbers of cells exhibiting neuronal morphology including DA neurons. TH positive axons from intracerebral grafts grew into regions of the dopamine-lesioned host striatal gray matter (Kleppner et al., 1995; Morassutti et al., 1994; Wojcik et al., 1993; Miyazono et al., 1995; Isacson \& Deacon 1996; Hemmati-Brivanlou \& Melton, 1997). Then a further study in which with low numbers of undifferentiated mouse ESCs implanted into the rat DA-depleted striatum, the cells proliferated and differentiated into functional DA neurons that reduced Parkinsonism (Björklund et al., 2002). However, lethal teratomas developed in $20 \%$ of the animals. More studies have reported that transplantation with NPCs in vitro differentiated from ESCs could decrease the possibility of teratomas formation (Björklund et al., 2002). Highly enriched populations of NPCs were developed in vitro from mouse ESCs and then implanted into Parkinsonian rats. The engrafted cells led to the recovery from Parkinsonism, and teratoma formation was not observed (Geeta et al., 2008). We also demonstrated that NPCs derived from MESPU35 mouse ES cell line grafted into the striatum of PD rats produced therapeutic effect evaluated with rotation test. The number of survival NPCs was increased significantly by fibronectin and over $90 \%$ of the engrafted NPCs were TH-positive 6 weeks after transplantation into the striatum of PD rats (Xu et al., 2004). There are no signs of tumor growth or non-neural tissue formation in the transplant recipients. It seemed that uncommitted mESC-derived NPCs could differentiate into DA neurons in host brain after transplantation, thereby leading to functional recovery (Kim et al., 2002). On the contrary, Ben-Hur et al has noticed that transplantation of uncommitted hESC-derived NPCs induced partial behavioral recovery, while there is no detectable DA neurons from grafted NPCs. 
The disparity may lie in the different biological characters of hNPCs compared to NPCs from mESCs when drived to DA differentiation (Ben-Hur et al., 2006). Ben-Hur et al has developed a simple protocol to harvest hNPCs from hESCs expressing transcripts of key regulatory genes of midbrain development, as well as markers of DA neurons, supporting their potential to differentiate into midbrain DA neurons. When these hNPCs grafted into the striatum of Parkinsonian rats, they survived for at least 12 weeks and differentiated in vivo into DA neurons. Transplanted Parkinsonian rats also exhibited significant behavioral recovery (Ben-Hur et al., 2006). Hence, induction of hNPCs differentiation toward a midbrain fate prior to transplantation is probably required for complete correction of behavioral deficit. In this regard, the host tissue probably could not direct the transplanted uncommitted hESC-derived NPCs to acquire a dopaminergic fate. The partial functional recovery induced by transplantation of uncommitted hESC-derived NPCs maybe due to the 'trophic' support provided by undifferentiated grafted cells within the damaged tissue (so called 'bystander effect').

Although NPCs might have greater developmental plasticity to respond to host environmental inductive cues that guide DA neuron differentiation, the adult striatum is probably unlikely to retain all instructive signals for DA neuron development from these. Therefore, pre-differentiation of ESCs into neural cells of a certain maturation stage is a prerequisite for obtaining a larger number of graft-derived DA neurons. It has been confirmed that ESCs-derived neurons carrying features of the ventral midbrain dopaminergic SN neurons will express En1, Pitx3, Nurr1, Lmx1b and Girk2, and will be labeled with dopaminergic markers, such as the dopamine transporter, vesicular monoamine transporter and the enzyme aromatic amino acid decarboxylase (Wernig et al., 2008). Signaling factors involved in CNS development have been used to control the differentiation of ESCs into mesencephalic dopamine (mesDA) neurons (Ye et al., 1998). Studies have used neurotrophic factors and overexpression of midbrain-specific genes to induce a dopaminergic phenotype in mouse ESC-derived neurons (McKay et al., 2006). It is well known that Shh, FGF8, Wnts affect the local environment in which mesDA neurons are generated during embryogenesis. However, these molecules underlie the regional specification of several cell types generated in midbrain (MB) and hindbrain during CNS development (Ling et al., 1998; Potter et al., 1999; Storch et al., 2001; Hynes \& Rosenthal 1999; Wurst \& Bally-Cuif,2001; Lee et al., 2000; Horiguchi et al., 2004) . As a consequence, in addition to mesDA neurons, cultures also include other regionally related neuronal subtypes such as serotonergic and GABAergic neurons (Deacon et al., 1998). Importantly, when used in cell therapy, some of these contaminating neuronal types may cause unwanted side effects after grafting. Thus, heterogeneity complicates development of a therapeutic application of stem cells and emphasizes the importance of developing methods that can generate highly enriched cultures of mesDA neurons. It is crucial to identify the fate-determining regulatory factors that influence dopamine cell fate decision and the underlying molecular machinery.

Neurotrophic factors and overexpression of midbrain-specific genes have been used to induce a dopaminergic phenotype in mouse ESCs-derived neurons. In vitro studies have shown that Shh, FGF-8, ascorbic acid, TGF- $\beta$ and cyclic AMP all increase the differentiation of DA neuron in culture (Ye et al., 1998). One of the most effective inducers of a dopaminergic fate comes from stromal-derived inducing activity from co-culture with stromal cell lines such as PA6 and MS5 (Kawasaki et al., 2000). It will be important to define the specific developmental stage of such committed precursors that will result in optimal 
survival, functional integration, and behavioral effects. A great deal of progress has been made in recent years in identifying transcription regulators that control the specification, migration and functional maintenance of mesDA neurons, providing insight into the generation of these cells in vitro and in vivo(Kim et al., 2002; Andersson et al., 2006). Researchers have over-expressed genes and transcription factors such as Nurr1, Pitx3 and Lmx1a known to promote the development of midbrain DA neurons resulting in much higher yields of DA neurons in vitro and in vivo (Kim et al., 2003; O'Keeffe et al., 2008; Chung et al. ,2005)

For DA neuron production from ESCs, genetic manipulation of transcription factors is by far the most effective approach. However, it is still in question how typical active ventral midbrain cell population contributes to functional reconstitution in PD brain. It can be determined by systematic transplantation studies using purified, molecularly defined cell populations from the developing midbrain. Studies on normal development of the midbrain DA lineage can help to analyze the molecular make up of cells at each step of DA lineage differentiation. It will be promising to determine the desired 'donor' cells for PD treatment from heterogeneous populations of differentiated ESCs progeny.

\subsection{Huntington's disease}

$\mathrm{HD}$ is a fatal hereditary and neurodegenerative disease characterized by involuntary choreiformic movements, cognitive impairment, and emotional disorder. In United States, there are nearly $30000 \mathrm{HD}$ patients and 150000 are in high risk (Leegwater-Kim \& Cha, 2004). HD is caused by mutation of a gene, which resulted in an abnormal expansion of CAG-encoded polyglutamine repeats in a protein called huntingtin (Walker, 2007). The presence of huntingtin leads to the loss of medium spiny neurons(GABAergic neurons) in the striatum, and to a lesser extent, in other extrapyramidal and cortical areas(Melone et al., 2005). Current pharmacotherapies of HD have been evaluated targeting the neurotransmitters such as GABA, dopamine, glutamate which are regarded as the predominant neurotransmitters affected in HD, however, few well conducted trials for symptomatic or neuroprotective interventions have yielded positive results. There is no current method to change the course of HD (Frank \& Jankovic, 2010).

Since the hallmark of HD is the loss of some specific neurons in the striatum and other regions in the brain, cell transplantation may serve as a hopeful strategy for reducing neural damage and replacing the lost neurons in the HD brain (Bachoud-Lévi et al., 2000; Dunnett \& Rosser, 2007; Kim et al., 2008; Clelland et al., 2008; Schwarz \& Schwarz, 2010). As early as 1983, Deckel et al transplanted fetal rat striatal tissues fragments into the KA-injured striatum and behavioral improvement was reported (Deckel et al., 1983). In 1995 Isacson et al transplanted embryonic porcine neural cells into adult rat brains with neuronal and axonal loss typical of HD, and found donor axons in host white matter tracts sprouting a long distance from transplant sites, it demonstrated that adult host brain can orient growth of transplanted neurons in cellular repair of the mature CNS (Isacson et al., 1995). This directly proved that transplanted xenogeneic neural cells in neurodegenerative disease models exhibit remarkable axonal target specificity and distinct growth patterns of glial and axonal fibers. Subsequently, numerous cellular therapy in excitotoxic striatal lesion HD animal models were reported, these transplantation experiments were carried out in HD animal models including mice, rats and monkeys (Bernreuther et al., 2006; Isacson et al., 1989). The transplanted cells derived from embryonic striatal tissues can survive and differentiate into the cell types of the normal striatum, the behavioral performance of the 
HD models were also improved (Bernreuther et al., 2006; Emerich et al., 1998). However, in transgenic mice, the authentic HD animal model, striatal cell transplantation only produced a limited effect on behavioral function (Gutekunst et al.,2000).

The clinical study of cell-based therapy on HD was conducted in Mexico in 1990, after that several reports from several countries showed that the human fetal striatal transplants could survive in the striatum without displacing the surrounding tissue (Gallina et al.,2010; Capetian et al., 2009; Hauser et al., 2002). Furthermore, human fetuses from ganglionic eminences (GE) transplanted into patients had shown long-term success (Bachoud-Lévi et al., 2006; Bachoud-Lévi et al., 2000). The striatal tissues and GE used in these cell-based treatment were isolated from the spontaneously aborted fetuses or selective abortions. The ethical and social issues of using human fetal tissues are still the major obstacles in the cell based replacement in HD.

ESCs have the potential to divide indefinitely in culture, producing unlimited cell source for cell-based therapy, which is considered as a major advantage. The production of NPCs from ESCs is the practical strategy of ESCs based cell transplantation for HD (Song et al., 2007; Bosch et .,2004; Bernreuther et al., 2006). Song and colleagues differentiated hESC into hNPs by co-culturing with PA6 stromal cells, and subsequently transplanted them into the striatum of quinolinic acid(QA)-induced HD model (Song et al., 2007). The transplanted animals exhibited a behavioral recovery for 3 weeks after transplantation (Song et al., 2007). It suggested that hESC-derived hNPCs can lead to a behavioral recovery, as well as neuronal differentiation in HD model. However, hESC-derived hNPCs differentiated into limited number of GABAergic neurons in this way, which is selected death in HD. One research group has generated a homogenous population of functional GABAergic neurons from a NSCs line, using retinoic acid and potassium chloride depolarization (Bosch et al., 2004). When transplanted in the QA model, these cells survived and improved functional deficits in vivo (Bosch et al., 2004). Restoring the lost brain functions by replacing damaged striatal neurons will be a crucial step to develop efficient cell replacement therapy in HD.

Recently, several protocols have been developed to produce striatal medium-spiny GABAergic neurons. L1-transfected mESCs cell line generated by Bernreuther et al showed decreased cell proliferation in vitro, enhanced neuronal differentiation in vitro and in vivo. Mice grafted with NPCs derived from L1-transfected ESCs showed functional recovery as decreasing rotation behavior 1 and 4 weeks post-transplantation and increased yield of GABAergic neurons and enhanced NPCs derived from ESCs migration into the lesioned striatum (Bernreuther et al., 2006). Thus L1 overexpression in the ESCs provides an efficient way to get striatal medium-spiny GABAergic neurons to treat HD. In one recent study, mESC line transfected with the extracellular matrix molecule tenascin-R (TNR), which is expressed by striatal GABAergic neurons, showed enhanced differentiation into neurons in vitro, reduced migration in vitro and in vivo (Hargus et al., 2008). Mice grafted with NPCs generated from TNR-transfected ESCs produced more GABAergic neurons and less astrocytes in grafts 1 month and 2 months after transplantation into the QA-treated striatum. Moreover, TNR-overexpressing ESCs transplanted into the striatum attracted hostderived neuroblasts from the rostral migratory stream and promoted recruitment of hostderived newborn neurons within the grafted area (Hargus et al., 2008). These indicated that both L1 and TNR guide ESCs to differentiate to GABAergic neurons, although they share different mechanism. It is likely that a combination of different molecular cues including recognition molecules, neurotrophic factors, and extracellular matrix molecules with cell transplantation will lead to at least additive effects on functional recovery in HD treatment. 
In another study, Aubry et al has designed an in vitro protocol to push hESCs along the neural lineage, up to postmitotic neurons that exhibit phenotypic features of the mediumspiny GABAergic neurons (MSNs) of the striatum (Aubry et al., 2008). hESCs-derived striatal progenitors have been shown efficiency differentiation into striatal GABAergic neurons following xenotransplantation into adult rats. Such these hESCs-derived striatal progeny may provide a potential cell therapy product to substitute for fetal neural precursors that are currently used in clinical trials to treat patients with HD. On the other hand, apparent overgrowth of human xenograft in rat brain was observed, the hyperplasia of grafted ESCs derived NPCs in the brain should take into account. Vazey et al reported that excessive proliferation was observed in the brain of HD rats in the spontaneouslyinduced hNPCs group 8 weeks post-transplantation (Vazey et al., 2006). Similar result has also been reported in a recent study when using MS5 stromal-induced hNP to graft into the QA lesioned striatum, significant numbers of transplant-derived overgrowths could not be identified until eight weeks post-transplantation. Vazey et al further demonstrated that noggin-primed hNPs have a greater capacity to survive long-term and differentiate into neurons than spontaneously-derived hNPs after transplanted into the striatum of QAinduced HD model (Vazey et al., 2010). In addition, hyperplasic growths and aberrant differentiation were efficiently controlled by noggin-primed hNPs transplantation even up to 8 weeks post transplantation, which suggested that noggin-primed hNPs transplantation provides an effective and safe treatment for HD.

\subsection{Amyotrophic lateral sclerosis}

ALS, also known as Lou Gehrig`s disease, is an adult-onset neurodegenerative disorder characterized by the gradual degeneration and death of motor neurons in the cerebral cortex, brain stem and spinal cord. The loss of motor neurons in the long run resulted in progressive paralysis and death within two to five years after diagnosis. The vast majority of ALS cases are sporadic (sALS), while approximately $5-10 \%$ of cases are inherited (known as familial; fALS) (Gros-Louis et al., 2006). Mutation in genes including cytosolic $\mathrm{Cu} / \mathrm{Zn}$ superoxide dismutase (SOD1), alsin, senataxin, synaptobrevin/VAMP (vesicle-associated membrane protein-associated protein B) and dynactin have been reported to cause fALS (Rosen et al., 1993; Yang et al., 2001; Hadano et al., 2001; Chance, 1998; Chen et al., 2004; Nishimura et al., 2004). Transgenic rodents carrying mutant human SOD1 genes appear many of the clinical and neuropathological features of familial as well as sporadic ALS, seem to be one useful model of the disease for preclinical studies. Several mechanisms are possibly involved in the etiology of motor neuron degeneration in ALS such as glutamate excitotoxicity, impaired axonal transportation, protein misfolding, cytoskeletal abnormalities and exposure to toxic or infectious agents. Currently, many evidences have shown that the activation and proliferation of astrocytes and microglia appeared common in ALS are regarded as another possible cause for motor neuron degeneration in ALS (Barbeito LH et al., 2004). Riluzole (Rilutek) is the first FDA-approved medicine for ALS, used to reduce motor neurons damage by decreasing the release of glutamate, which only prolongs patient survival by several months (Gurney et al., 1998). Other potential therapies for ALS, which partially alleviated symptoms has been shown in human clinical trials. So far, there is no effective treatment to cure the patients suffering from ALS.

As the lack of effective drug treatments and the typical pathological changes of ALS are the degeneration and loss of motor neurons in the CNS, cell replacement is considered as a 
promising treatment strategy. $\mathrm{Xu}$ and colleagues used NSCs from human fetal spinal cord in the transplantation experiments of SOD1 transgenic ALS rats (Xu et al., 2006). The grafted hNSCs were found to differentiate into neurons and formed synapse, secreting several neurotrophic factors, and the degeneration progression of motor neurons in this ALS model was delayed ( $\mathrm{Xu}$ et al., 2006). It suggested that NSCs grafts can survive well in a ALS environment and the functional improvement was partly caused by the motor neuron growth factors released by grafted NSCs. Intrathecal transplantation of immortalized human NSCs overexpressing vascular endothelial growth factor(VEGF) gene was also reported to significantly delay the onset and prolonged the survival of the SOD1G93A mouse model of ALS. By concomitant downregulation of proapoptotic proteins and upregulation of antiapoptotic proteins, the transplanted human NSCs provided neuroprotective effect in the spinal cord of ALS (Hwang et al., 2009). Recently Mitrecić and colleagues compared the efficiency of NSCs delivery to the CNS in ALS at different stages and found that NSCs via intravenous tail vein injections enter the CNS affected by inflammation/degeneration, the highest delivery efficiency was found in symptomatic ALS and moderate in presymptomatic ALS, while the lowest in wild-type group (Mitrecić et al., 2010). The grafted NSCs preferentially localize in the motor cortex, hippocampus, and spinal cord.

Considering the human NSCs usually isolated from fetal spinal cord or brains, the ethics obstacles make it unsuitable in clinical application. ESCs as totipotent cell are able to differentiate into motor neurons under defined conditions (Nizzardo et al., 2010 ; Li et al., 2008; Soundararajan et al.,2007). Evidences have shown that developmentally relevant signaling factors such as retinoid acid (RA) and sonic hedgehog (Shh) can induce mouse ESCs to differentiate into spinal progenitor cells, and subsequently into motor neurons (Hu \& Zhang, 2010; Kim et al., 2009; Li et al., 2008). When transplanted into embryonic chick or adult rat spinal cords, ESCs cell-derived motor neurons can populate the embryonic spinal cord, extend axons, and form synapses with target muscles (Goldstein, 2010). In the similar approaches used for mouse ESCs with small modification, it has been successful in generation of spinal motor neurons from human ESCs in an adherent culture. In terms of the initial neural induction, human ESCs, require FGF2 or those generated from co-cultured feeder cells, then treated with a combination of Shh and RA to generate spinal motor neurons efficiently (Hu \& Zhang, 2010). The in vitro-generated motor neurons from human ESCs expressed HB9, HoxC8, choline acetyltransferase and vesicular acetylcholine transporter, form synapses on co-cultured myoblasts/myotubes and are electrophysiologically active(Li et al., 2005). These indicate that ESCs are promising donor cells for supplying motor neurons. High purified generation of motor neurons can improve safety, due to decreased number of cells for transplantation. Most recently, Li has described a simple chemically defined suspension culture generated $50 \%$ efficiency of motor neuron differentiation from human and primate ESCs treated with purmorphamine, a small molecule that activates the Shh pathway ( $\mathrm{Li}$ et al., 2008). Furthermore, stable transfection of human and mouse ESCs with $\mathrm{Hb} 9$ promoter-driven green fluorescent protein genes, followed by a further isolation of the green cells by fluorescence-activated cell sorting (FACS), could generate enrichment of the motor neuron population from ESCs (Giudice \& Trounson, 2008).

In vivo studies, ESCs are seemed to be promising cell sources of cell based treatment of ALS. The study reported that the expression of $\mathrm{Hb} 9$ could directly induce mouse ESCs into cholinergic motor neurons. When transplanted into the spinal cord, these ESCs-derived 
motor neurons were observed to extend the axons and form synapses with muscles (Giudice $\&$ Trounson, 2008). Domos and colleagues had generated iPSCs from an 82-year-old with familial ALS woman and successfully directed to differentiate into motor neurons. These patient-specific iPSCs possess properties of ESCs and supposed to be used in the cell transplantation of ALS (Dimos et al., 2008). Recently, López-González et al differentiated mouse ESCs into motor neurons and grafted into the lumbar spinal cord of hSOD1(G93A) ALS rats. They found that grafted cells with motor neuron phenotype can survive for at least 1 week in hSOD1(G93A) animals and the significant improvement in movement was transiently recovered, However, the long-term effect of cell transplantation was not guaranteed because the transgenic hSOD1(G93A) environment is detrimental to grafted motor neurons (Lopez-Gonzalez et al., 2009).

Glial cells such as astrocytes and microglias create a hostile environment that contributes to motor neuron toxicity in transgenic ALS animal models and then may also adversely affect the survival and maturation of transplanted stem cell derived-motor neurons. Makiko has demonstrated that rodent astrocytes expressing mutated SOD1 kill spinal primary and mouse ESCs-derived motor neurons without leading to the death of spinal GABAergic or dorsal root ganglion neurons or ESCs-derived interneurons (Nagai et al., 2007). Conversely, expression of mutated human SOD1 in primary mouse spinal motor neurons does not provoke motor neuron degeneration (Nagai et al., 2007). These findings suggest that astrocytes may play a role in the specific degeneration of spinal motor neurons in ALS. Marchetto et al co-cultured human ESCs-derived motor neurons with human primary astrocytes expressing mutated SOD1 and found that a selective motor neuron toxicity was correlated with increased inflammatory response in SOD1-mutated astrocytes (Marchetto et al., 2008). Consistent with this study, it has been confirmed that human ESCs-derived motor neurons are selectively sensitive to toxic effect caused by astrocytes carrying an ALS-causing mutation in the SOD1, while interneuron populations produced from ESCs are unaffected (Di Giorgio et al., 2008). Taken together, these studies suggest a scenario in which mutation of SOD1 activates inflammatory pathways in astrocytes, including activation of prostaglandin D2(PGD2) signaling and nitric oxide release. Furthermore, primary motor neurons co-cultured in direct contact, particularly with primary mutant SOD1-expressing microglia, showed decreased survival and shortened neurite length (Zhao et al., 2010). As further evidence for microglial toxicity to motor neurons in ALS, several studies have indicated that isolated primary microglia become toxic to primary motor neurons when activated with either proinflammatory LPS or IgG immune complexes isolated from human ALS patients (Thonhoff et al., 2009; Weydt et al., 2004; Dewil et al., 2007).

Different from other neurodegenerative diseases, both the motor neurons and non-neuronal cells (mainly astrocyte or microglial) should be taken into account in the stem cell replacement of ALS. When using ESCs transplantation treating ALS, the replacement of dysfunctional non-neuronal glial cells such as astrocytes and microglia will be helpful to protect motor neurons.

\section{Prospects and conclusions}

Although ESCs transplantation has been proved to be a promising tool and potential therapies for treating incurable neurodegenerative diseases such as AD, PD, HD, and ALS, it is too early to be optimistic that ESCs will be used immediately clinically to cure the neurodegenerative diseases. Several issues about safety, effectiveness, ethical and feasibility 
must be considered before the adoption of stem cell replacement is widely accepted in clinical medicine. The risk of tumorigenesis is primary consideration of ESCs replacement in patients suffered from neurodegenerative diseases. The small number of ESCs escape differentiation and selection procedure may over proliferate and bring the risk of teratoma formation (Rao, 2007). With development of procedures to produce high purified NPCs with commitment and mature neurons derived from human ESCs is safe in cell transplantation of neurological diseases. It has been achieved to generate enrichment neuron or NPC populations from ESCs, while the efficiency to produce more specific neuron such as DA neuron is very low. It maybe overcomed by uncovering the developmental mechanism and improved techniques (Cho et al., 2008). It seemed effective when ESCs were used in the transplantation experiments in the animal models of neurodegenerative diseases, but the long term effects related to security and recovery of structure and function need to be evaluated carefully before clinical practice.

The ethical and feasibility problems of ESCs based treatment in neurodegenerative disease are also expected to be solved in near future. The success in iPSCs seems to offer the advantages of hESCs without the ethical and rejection problems, although the iPSCs is not as versatile and plastic as ESCs. Revazova and collegues have established four unique HLAhomozygous human ESCs lines which have a simple genetic profile in the critical areas of the DNA that code for immune rejection, these ES cell lines will not provoke an immune reaction in large segments of the population and could serve to create a stem cell bank as a renewable source of transplantable cells for use in cell therapy to treat degenerative diseases (Revazova et al., 2008).

In conclusion, although there is still a long way to go in ESCs replacement therapy to become a clinical reality for AD, PD, HD and ALS, this therapeutic approach is promising for neurodegenerative diseases.

\section{Acknowledgements}

This work was granted by National Natural Sciences Foundation of China (31071299, 31070927)

\section{References}

Andersson, E.; Tryggvason, U.; Deng, Q.; Friling, S.; Alekseenko, Z.; Robert, B.; Perlmann, T. \& Ericson, J.(2006). Identification of intrinsic determinants of midbrain dopamine neurons. Cell., Vol.124, No.2,(Jan 2006) pp.393-405, ISSN

Agid, Y.(1991). Parkinson's disease: pathophysiology. Lancet., Vol.337, No.8753,(Jun 1991) pp. 1321-1324, ISSN

Aldskogius, H.; Berens, C.; Kanaykina, N.; Liakhovitskaia, A.; Medvinsky, A.; Sandelin, M.; Schreiner, S.; Wegner, M.; Hjerling-Leffler, J. \& Kozlova, EN. (2009). Regulation of boundary cap neural crest stem cell differentiation after transplantation. Stem cells., Vol.27, NO.7, (Jul 2009) pp.1592-1603, ISSN

Angel Cedazo-Mínguez.(2007). Apolipoprotein E and Alzheimer's disease: molecular mechanisms and therapeutic opportunities. J Cell Mol Med., Vol 11, No 6, (Nov.Dec.2007) pp. 1227-1238,ISSN

Anjomshoa, M.; Karbalaie, K.; Mardani, M.; Razavi, S.; Tanhaei, S.; Nasr-Esfahani, M.H. \& Baharvand, H.(2009). Generation of motor neurons by coculture of retinoic acid- 
pretreated embryonic stem cells with chicken notochords. Stem Cells Dev., Vol.18, No.2, (Mar 2009) pp.259-267,ISSN

Arvidsson, A.; Collin, T.; Kirik, D.; Kokaia. Z. \& Lindvall, O. (2002). Neuronal replacement from endogenous precursors in the adult brain after stroke. Nat Med., Vol.8,No.9, (Sep 2002) pp. 963-970,ISSN

Aubry, L.; Bugi, A.; Lefort, N.; Rousseau, F.; Peschanski, M. \& Perrier, A.L.(2008). Striatal progenitors derived from human ES cells mature into DARPP32 neurons in vitro and in quinolinic acid-lesioned rats. Proc Natl Acad Sci U S A., Vol.105,No.43,(Oct 2008)pp.16707-16712,ISSN

Bachoud-Lévi, A.C.; Rémy, P.; Nguyen, J.P.; Brugières, P.; Lefaucheur, J.P.; Bourdet, C.; Baudic, S.; Gaura, V.; Maison, P.; Haddad, B.; Boissé, M.F.; Grandmougin, T.; Jény, R.; Bartolomeo, P.; Dalla, Barba, G.; Degos, J.D.; Lisovoski, F.; Ergis, A.M.; Pailhous, E.; Cesaro, P.; Hantraye, P. \& Peschanski, M.(2000).Motor and cognitive improvements in patients with Huntington's disease after neural transplantation. Lancet., Vol.356,No.9246,( Dec 2000)pp.1975-1979,ISSN

Bachoud-Lévi, A.C.; Gaura, V.; Brugieres, P.; Lefaucheur, J.P.;Boisse, M.F.; Maison, P.; Baudic, S.; Ribeiro, M.J.;Bourdet, C.; Remy, P.; Cesaro, P.; Hantraye, P. \& Peschanski, M.(2006). Effect of fetal neural transplants in patients with Huntington's disease 6 years after surgery: A long-term follow-up study. Lancet Neurol., Vol.5,No.4,(2006)pp.303-309,ISSN

Barbeito, L.H.; Pehar, M.; Cassina, P.; Vargas, M.R.; Peluffo, H.; Viera, L.; Estévez, A.G.\& Beckman, J.S.(2004). A role for astrocytes in motor neuron loss in amyotrophic lateral sclerosis. Brain Res Brain Res Rev., Vol. 47,No. 1-3, (Dec 2004) pp. 263274.ISSN

Baylis, F. (2008). Animal eggs for stem cell research: a path not worth taking. Am J Bioeth.,Vol.8, No.12,(Dec 2008) pp.18-32,ISSN

Ben-Hur, T.; Idelson, M.; Khaner, H.; Pera, M.; Reinhartz, E.; Itzik, A. \& Reubinoff, B.E.(2006).Transplantation of human embryonic stem cell-derived neural progenitors improves behavioral deficit in Parkinsonian rats. Stem Cells., Vol. 22,No. 7, (Feb 2006) pp.1246-1255, ISSN

Benzing, C.; Segschneider, M.; Leinhaas, A.; Itskovitz-Eldor, J. \& Brüstle, O. (2006). Neural conversion of human embryonic stem cell colonies in the presence of fibroblast growth factor-2. Neuroreport., Vol.17, No.16, (Nov 2006) pp.1675-1681,ISSN

Bernreuther, C.; Dihné, M.; Johann, V.; Schiefer, J.; Cui, Y.; Hargus, G.; Schmid, J.S.; Xu, J.; Kosinski, C.M. \& Schachner, M.(2006). Neural cell adhesion molecule L1transfected embryonic stem cells promote functional recovery after excitotoxic lesion of the mouse striatum.J Neurosci., Vol.26,No.45,(Nov 2006)pp.1153211539,ISSN

Bicknese, A.R.; Goodwin, H.S.; Quinn, C.O.; Henderson, V.C.; Chien, S.N.\& Wall, D.A. (2002). Human umbilical cord blood cells can be induced to express markers for neurons and glia. Cell Transplant.,Vol. 11, No.3, (2002) pp.261-264,ISSN

Björklund, A. (2005). Cell therapy for Parkinson's disease: problems and prospects. Novartis Found Symp., Vol.265, (2005) pp.174-86; discussion Vol.187, pp. 204-211,ISSN

Björklund, L.M.; Sánchez-Pernaute, R.; Chung, S.; Andersson, T.; Chen, I.Y.; McNaught, K.S.;Brownell, A.L.; Jenkins, B.G.; Wahlestedt, C.; Kim, K.S. \& Isacson, O.(2002).Embryonic stem cells develop into functional dopaminergic neurons after 
transplantation in a Parkinson rat model. Proc Natl Acad Sci U S A. ,Vol.99, No.4, (Feb 2002) pp.2344-2349, ISSN

Blennow, K.; de Leon, M.J. \& Zetterberg, H. (2006). Alzheimer's disease. Lancet., Vol.368, NO.9533, (Jul 2006) pp.387-403,ISSN

Boncristiano, S.; Calhoun, ME.; Kelly, P.H.; Pfeifer, M.; Bondolfi, L.; Stalder, M.; Phinney, A.L.; Abramowski, D.; Sturchler-Pierrat, C.; Enz, A.; Sommer, B.; Staufenbiel, M. \& Jucker, M. (2002). Cholinergic changes in the APP23 transgenic mouse model of cerebral amyloidosis. J Neurosci., Vol.22, No.8, (Apr 2002)pp.3234-3243, ISSN

Brookmeyer, R.; Gray, S. \& Kawas, C.(1998). Projections of Alzheimer's disease in the United States and the public health impact of delaying disease onset. Am J Public Health., Vol.88, NO.9,( Sep 1998) pp.1337-1342,ISSN

Brookmeyer, R.; Johnson, E.; Ziegler-Graham, K \& Arrighi, H.M.(2007). Forecasting the global burden of Alzheimer's disease. Alzheimers Dement., Vol.3, No.3, (July 2007) pp.186-191, ISSN

Bosch, M.; Pineda, J.R.; Sunol, C.; Petriz, J.; Cattaneo, E.; Alberch, J. \& Canals, J.M.(2004). Induction of GABAergic phenotype in a neural stem cell line for transplantation in an excitotoxic model of Huntington's disease. Exp Neurol., Vol.190,No.1,(Nov 2004)pp.42-58,ISSN

Cai, J. \& Rao, M. (2007). Stem and precursor cells for transplant therapy, In: Cellular Transplantation. From Laboratory to Clinic, Craig Halberstadt, Dwaine F. Emerich, (Ed.), pp.29-42Academic Press., ISBN

Cajánek, L.; Ribeiro, D.; Liste, I.; Parish, C. L.; Bryja, V. \& Arenas, E. (2009). Wnt/betacatenin signaling blockade promotes neuronal induction and dopaminergic differentiation in embryonic stem cells. Stem Cells., Vol.27,NO.12, (Dec 2009)pp.2917-27,ISSN

Cao, Q.; Benton, R.L. \& Whittemore, S.R. (2002). Stem cell repair of central nervous system injury. J Neurosci Res., Vol. 68, No.5, (Jun 2002) pp. 501-510,ISSN

Capetian, P.; Knoth, R.; Maciaczyk, J.; Pantazis, G.; Ditter, M.; Bokla, L.; Landwehrmeyer, G.B.; Volk, B. \& Nikkhah, G.(2009). Histological findings on fetal striatal grafts in a Huntington's disease patient early after transplantation. Neuroscience., Vol.160,No.3,(May 2009)pp.661-675,ISSN

Chambers, S.M.; Fasano, C.A.; Papapetrou, E.P.; Tomishima, M.; Sadelain, M. \& Studer, L. (2009). Highly efficient neural conversion of human ES and iPS cells by dual inhibition of SMAD signaling. Nat Biotechnol., Vol.27, No. 3, (Mar 2009) pp.275280,ISSN

Chance, P.F.; Rabin, B.A.; Ryan, S.G.; Ding ,Y.; Scavina, M.; Crain, B.; Griffin, J.W. \& Cornblath, D.R.(1998).Linkage of the gene for an autosomal dominant form of juvenile amyotrophic lateral sclerosis to chromosome 9q34. Am J Hum Genet., Vol.62,No.3, (Mar 1998) pp.633-640,ISSN

Chen, Y.Z.; Bennett, C.L.; Huynh, H.M.; Blair, I.P.; Puls, I.; Irobi, J.; Dierick, I.; Abel, A.; Kennerson, M.L.; Rabin, B.A.; Nicholson, G.A.; Auer-Grumbach, M.; Wagner, K.; De Jonghe, P.; Griffin, J.W.; Fischbeck, K.H.; Timmerman, V.; Cornblath, D.R. \& Chance, P.F.(2004).DNA/RNA helicase gene mutations in a form of juvenile amyotrophic lateral sclerosis (ALS4). Am J Hum Genet., Vol.74,No.6, (Apr 2004) pp.1128-1135,ISSN 
Cheng, L.; Hammond, H.; Ye, Z.; Zhan, X. \& Dravid, G. (2003). Human adult marrow cells support prolonged expansion of human embryonic stem cells in culture. Stem Cells., Vol. 21, No.2, (Mar 2003) pp. 131-142,ISSN

Cho, M.S.; Lee, Y.E.; Kim, J.Y.; Chung, S.; Cho, Y.H.; Kim, D.S.; Kang, S.M.; Lee, H.; Kim, M.H.; Kim, J.H.; Leem, J.W.; Oh, S.K.; Choi, Y.M.; Hwang, D.Y.; Chang, J.W.\& Kim, D.W. (2008).Highly efficient and large-scale generation of functional dopamine neurons from human embryonic stem cells. Proc Natl Acad Sci USA., Vol. 105, No. 9, (Mar 2008) pp.3392-3397, ISSN

Chua, S.J.; Bielecki, R.; Wong, C.J.;Yamanaka, N.; Rogers, I.M. \& Casper, R. F. (2009). Neural progenitors, neurons and oligodendrocytes from human umbilical cord blood cells in a serum-free, feeder-free cell culture. Biochem Biophys Res Commun.,Vol. 379, No. 2,(Feb 2009) pp.217-221,ISSN

Chung, S.; Hedlund, E.; Hwang, M.; Kim, D. W.; Shin, B.S.; Hwang, D.Y.; Jung Kang, U.; Isacson, O. \& Kim, K.S. (2005). The homeodomain transcription factor Pitx3 facilitates differentiation of mouse embryonic stem cells into AHD2-expressing dopaminergic neurons. Mol Cell Neurosc., Vol.28, No. 2, (Feb 2005) pp.241-252, ISSN

Clelland, C.D.; Barker, R.A. \& Watts, C.(2008).Cell therapy in Huntington disease. Neurosurg Focus., Vol.24,No.3-4,(2008) E9.

Consiglio, A.; Gritti, A.; Dolcetta, D.; Follenzi, A.; Bordignon, C.; Gage, F.H.; Vescovi, A.L.\& Naldini, L. (2004). Robust in vivo gene transfer into adult mammalian neural stem cells by lentiviral vectors. Proc Natl Acad Sci U S A., Vol.101,No.41,(Oct 2004) pp.14835-14840,ISSN

De Filippis, L.; Ferrari, D.; Rota Nodari, L.; Amati, B.; Snyder, E. \& Vescovi, A.L. (2008). Immortalization of human neural stem cells with the c-myc mutant T58A. PloS one., Vol.3, No.10, (Oct 2008) pp. e3310,ISSN

Deacon, T.; Dinsmore, J.; Costantini, L.C.; Ratliff, J.; Isacson, O.(1998). Blastula-stage stem cells can differentiate into dopaminergic and serotonergic neurons after transplantation. Exp Neurol., Vol.149, No. 1,(Jan 1998) pp.28-41,ISSN

Deckel, A.W.; Robinson, R.G.; Coyle, J.T. \& Sanberg, P.R.(1983).Reversal of long-term locomotor abnormalities in the kainic acid model of Huntington's disease by day 18 fetal striatal implants. Eur J Pharmacol., Vol.93,No.3-4,(Sep 1983)pp.287-288,ISSN

Dewil, M.; dela Cruz,V.F.; Van Den Bosch,L. \& Robberecht, W.(2007).Inhibition of p38 mitogen activated protein kinase activation and mutant SOD1(G93A)-induced motor neuron death. Neurobiol Dis., Vol.26, No.2, (Feb 2007) pp.332-341,ISSN

Dhara, S.K.; Hasneen, K.; Machacek, D.W.; Boyd, N. L.; Rao, R. R.; \& Stice, S. L.; (2008). Human neural progenitor cells derived from embryonic stem cells in feeder-free cultures. Differentiation., Vol.76,NO.5, (May 2008)pp.454-464,ISSN

Dickens, B. M. \& Cook, R. J. (2007). Acquiring human embryos for stem-cell research. Int J Gynaecol Obstet., Vol.96, No.1, (Jan 2007) pp 67-71,ISSN

Di Fonzo, A.; Rohé, C.F.; Ferreira, J.; Chien, H.F.;Vacca, L.; Stocchi, F.; Guedes, L.;Fabrizio, E.; Manfredi, M.;Vanacore, N.; Goldwurm, S.; Breedveld, G.; Sampaio, C.; Meco, G.; Barbosa ,E.; Oostra,B.A.; Bonifati ,V.; Italian Parkinson Genetics Network.(2005).A frequent LRRK2 gene mutation associated with autosomal dominant Parkinson's disease. Lancet., Vol.365, No. 9457, (Jan-Feb 2005) pp. 412-415, ISSN 
Di Giorgio, F.P.; Boulting, G.L.; Bobrowicz, S. \& Eggan, K.C.(2008). Human embryonic stem cell-derived motor neurons are sensitive to the toxic effect of glial cells carrying an ALS-causing mutation. Stem Cell, Vol.3, No.6, (Dec 2008) pp.634-648,ISSN

Dimos, J.T.; Rodolfa, K.T. ; Niakan, K.K.; Weisenthal, L.M. ; Mitsumoto, H. ; Chung, W.; Croft, G.F. ; Saphier, G.; Leibel, R. ; Goland, R.; Wichterle, H.; Henderson, C.E., \& Eggan, K. (2008). Induced pluripotent stem cells generated from patients with ALS can be differentiated into motor neurons, Science., Vol.321, No.5893, (Aug 2008) pp.1218-1221,ISSN

Duan, X.; Kang, E.; Liu, C. Y.; Ming, G. L. \& Song, H. (2008).Development of neural stem cell in the adult brain. Curr Opin Neurobiol.,Vol.18,NO.1, (Feb 2008)pp.108-115,ISSN

Dunnett, S.B.; Björklund, A. (1999). Prospects for new restorative and neuroprotective treatments in Parkinson's disease. Nature., Vol.399(6738 Suppl), (Jun 1999) pp.A32A39, ISSN

Dunnett, S.B. \& Rosser, A.E.(2007).Stem cell transplantation for Huntington's disease. Exp Neurol., Vol.203,No.2, (Feb 2007)pp.279-92,ISSN

Emerich, D.F.; Bruhn, S.; Chu, Y. \& Kordower, J.H.(1998). Cellular delivery of CNTF but not NT-4/5 prevents degeneration of striatal neurons in a rodent model of Huntington's disease. Cell Transplant., Vol.7,No.2,(1998)pp.213-225,ISSN

Evans, M.J. \& Kaufman, M.H. (1981). Establishment in culture of pluripotent cells from mouse embryos. Nature., Vol.292,No.5819, (Jul 1981)pp.154-156,ISSN

Fahn, S.; Oakes, D.; Shoulson, I.; Kieburtz, K.; Rudolph, A.; Lang, A.; Olanow, C.W.; Tanner, C.; Marek, K.; Parkinson Study Group.(2004). Levodopa and the progression of Parkinson's disease. N Engl J Med., Vol.351, No.24,(Dec 2004) pp.2498-2508, ISSN

Fine, A.; Dunnett, S. B.; Björklund, A. \& Iversen S. D. (1985). Cholinergic ventral forebrain grafts into the neocortex improve passive avoidance memory in a rat model of Alzheimer disease. Proc Natl Acad Sci U S A., Vol. 82, No. 15, (Aug 1985)pp.52275230, ISSN

Frank, S. \& Jankovic, J.(2010). Advances in the pharmacological management of Huntington's disease. Drugs., Vol.70,No.5,( Mar 2010)pp.561-571,ISSN

Freed, C.R.; Greene, P.E.; Breeze, R.E.; Tsai, W.Y.; Mouchel, W.Du.; Kao, R.; Dillon, S. ; Winfield, H.; Culver, S.; Trojanowski, J.Q.; Eidelberg, D. \& Fahn, S. (2001). Transplantation of embryonic dopamine neurons for severe Parkinson's disease. $N$ Engl J Med., Vol.344, No. 10, (Mar 2001) pp. 710-719,ISSN

Freund, T.F.; Bolam, J.P.; Bjorklund, A.; Stenevi, U.; Dunnett, S.B.; Powell, J.F.\& Smith. A.D. (1985). Efferent synaptic connections of grafted dopaminergic neurons reinnervating the host neostriatum: a tyrosine hydroxylase immunocytochemical study. J Neurosci., Vol.5, No.3, (Mar 1985) pp.603-616, ISSN

Gallina, P.; Paganini, M.; Lombardini, L.; Mascalchi, M.; Porfirio, B.; Gadda, D.; Marini, M.; Pinzani, P.; Salvianti, F.; Crescioli, C.; Bucciantini, S.; Mechi, C.; Sarchielli, E.; Romoli, A.M.; Bertini, E.; Urbani, S.; Bartolozzi, B.; De Cristofaro, M.T.; Piacentini, S.; Saccardi, R.; Pupi, A.; Vannelli, G.B. \& Di-Lorenzo, N.(2010).Human striatal neuroblasts develop and build a striatal-like structure into the brain of Huntington's disease patients after transplantation. Exp Neurol., Vol.222,No.1,(Mar 2010)pp.30-41,ISSN

Geeta, R.; Ramnath, R.L.; Rao, H.S.; Chandra, V.(2008).One year survival and significant reversal of motor deficits in parkinsonian rats transplanted with hESC derived 
dopaminergic neurons. Biochem Biophys Res Commun., Vol.373, No.2, (Aug 2008) pp.258-264, ISSN

Giudice, A. \& Trounson, A.(2008). Genetic modification of human embryonic stem cells for derivation of target cells. Cell Stem Cell., Vol.2, No.5, (May 2008) pp.422-433,ISSN

Goings, G.E.; Sahni, V.; \& Szele, F.G.(2004). Migration patterns of subventricular zone cells in adult mice change after cerebral cortex injury. Brain Res., Vol.996, No.2, (Jan 2004) pp. 213-226, ISSN

Goldstein, R.S.(2010). Transplantation of human embryonic stem cells and derivatives to the chick embryo. Methods Mol Biol., Vol.584, (2010) pp.367-385,ISSN

Greschat, S.; Schira, J.; Küry, P.; Rosenbaum, C.; de Souza Silva, M.A.; Kögler, G.; Wernet, P.\& Müller, H. W. (2008). Unrestricted somatic stem cells from human umbilical cord blood can be differentiated into neurons with a dopaminergic phenotype. Stem Cells Dev., Vol.17, No. 2, (Apr 2008) pp. 221-232,ISSN

Gros-Louis, F.; Gaspar, C. \& Rouleau, G.A.(2006). Genetics of familial and sporadic amyotrophic lateral sclerosis. Biochim Biophys Acta., Vol. 1762, No.11-12, (Nov-Dec 2006)pp. 956-972,ISSN

Guan, K.; Chang, H.; Rolletschek, A.\& Wobus, A. M. (2001).Embryonic stem cell-derived neurogenesis. Retinoic acid induction and lineage selection of neuronal cells. Cell Tissue Res., Vol.305,NO.2, (Aug 2001)pp.171-176,ISSN

Gurney, M.E.; Fleck, T.J.; Himes,C.S. \& Hall, E.D.(1998). Riluzole preserves motor function in a transgenic model of familial amyotrophic lateral sclerosis. Neurology., Vol. 50, No.1,( Jan 1998)pp.62-66,ISSN

Gutekunst, C.A.; Norflus, F. \& Hersch, S.M.(2000). Recent advances in Huntington's disease. Curr Opin Neurol., Vol.13,No.4,(Aug 2000)pp.445-450,ISSN

Hadano, S.; Hand, C.K.; Osuga, H.; Yanagisawa, Y.; Otomo, A.; Devon, R.S.; Miyamoto, N.; Showguchi-Miyata, J.; Okada, Y.; Singaraja, R.; Figlewicz, D.A.; Kwiatkowski, T.; Hosler, B.A.; Sagie, T.; Skaug, J.; Nasir, J.; Brown, R.H.Jr.; Scherer, S.W.; Rouleau, G.A.; Hayden, M.R. \& Ikeda, J.E.(2001). A gene encoding a putative GTPase regulator is mutated in familial amyotrophic lateral sclerosis 2. Nature Genet., Vol.29,No.2, (Oct 2001) pp.166-173,ISSN

Hardy, J.(2003).Impact of genetic analysis on Parkinson's disease research. Mov Disord., Vol.18(suppl 6), (Sep 2003) pp.S96-S98, ISSN

Hargus, G.; Cui, Y.; Schmid, J.S.; Xu, J.; Glatzel, M.; Schachner, M. \& Bernreuther, C.(2008). Tenascin-R Promotes neuronal differentiation of embryonic stem cells and recruitment of host-derived neural precursor cells after excitotoxic lesion of the mouse striatum. Stem cells., Vol.26,No.8,(Aug 2008)pp.1973-1984,ISSN

Hauser, R.A.; Furtado, S.; Cimino, C.R.; Delgado, H.; Eichler, S.; Schwartz, S.; Scott, D.; Nauert, G.M.; Soety, E.; Sossi, V.; Holt, D.A.; Sanberg, P.R.; Stoessl, A.J. \& Freeman, T.B.(2002).Bilateral human fetal striatal transplantation in Huntington's disease. Neurology., Vol.58,No.5,(Mar 2002)pp.687-695,ISSN

Hemmati-Brivanlou, A.; Melton, D.(1997). Vertebrate embryonic cells will become nerve cells unless told otherwise. Cell., Vol.88, No.1,(Jan 1997) pp.13-17, ISSN

Hiller, M.; Liu, C.F.; Blumenthal, P.D.; Gearhart, J. \& Kerr, C. (2010).Bone Morphogenetic Protein 4 Mediates Human Embryonic Germ Cell Derivation. Stem Cells Dev., [Epub ahead of print] (May 2010), ISSN 
Horiguchi, S.; Takahashi, J.; Kishi, Y.; Morizane, A.; Okamoto, Y.; Koyanagi, M.; Tsuji, M.; Tashiro, K.; Honjo, T.; Fujii, S. \& Hashimoto, N. (2004). Neural precursor cells derived from human embryonic brain retain regional specificity. J Neurosci Res., Vol.75, No.6, (Mar 2004) pp.817-824, ISSN

$\mathrm{Hu}$, B.Y. \& Zhang, S.C.(2010). Directed differentiation of neural-stem cells and subtypespecific neurons from hESCs. Methods Mol Biol., Vol.636, (2010)pp.123-137,ISSN

$\mathrm{Hu}$, B.Y. \& Zhang, S.C.(2009). Differentiation of spinal motor neurons from pluripotent human stem cells. Nat Protoc., Vol.4, No.9, (2009) pp.1259-1304,ISSN

Hwang, D.H.; Lee, H.J.; Park, I.H.; Seok, J.I.; Kim, B.G.; Joo, I.S. \& Kim, S.U.(2009). Intrathecal transplantation of human neural stem cells overexpressing VEGF provide behavioral improvement, disease onset delay and survival extension in transgenic ALS mice. Gene Ther., Vol.16, No.10, (Oct 2009)pp.1234-1244,ISSN

Hynes, M. \& Rosenthal, A. (1999).Specification of dopaminergic and serotonergic neurons in the vertebrate CNS. Curr Opin Neurobiol., Vol.9, No.1,(Feb 1999) pp.26-36,ISSN

Imitola J.(2007). Prospects for neural stem cell-based therapies for neurological diseases. Neurotherapeutics., Vol.4,NO.4, (Oct 2007)pp.701-714,ISSN

Isacson, O.; Riche, D.; Hantraye, P.; Sofroniew, M.V. \& Maziere, M.(1989). A primate model of Huntington's disease: cross-species implantation of striatal precursor cells to the excitotoxically lesioned baboon caudate-putamen. Exp Brain Res., Vol. 75, No. 1, (1989) pp.213-220,ISSN

Isacson, O.; Deacon, T.W.; Pakzaban, P.; Galpern, W.R.; Dinsmore, J. \& Burns, L.H.(1995). Transplanted xenogeneic neural cells in neurodegenerative disease models exhibit remarkable axonal target specificity and distinct growth patterns of glial and axonal fibres. Nat Med., Vol.1,No.11,(Nov 1995)pp.1189-1194,ISSN

Isacson, O.; Deacon, T.W.(1996).Specific axon guidance factors persist in the mature rat brain: evidence from fetal neuronal xenografts. Neuroscience., Vol.75,(1996) pp.827837, ISSN

Jankovic, J. (2008). Parkinson's disease: clinical features and diagnosis. J Neurol Neurosurg Psychiatry., Vol.79, No.4, (Apr 2008) pp.368-376, ISSN

Jin, K. \& Galvan, V. (2007). Endogenous neural stem cells in the adult brain. J Neuroimmune Pharmacol., Vol.2, No.3, (Sep 2007)pp. 236-242,ISSN

Kawasaki, H.; Mizuseki, K.; Nishikawa, S.; Kaneko, S.; Kuwana, Y.; Nakanishi, S.; Nishikawa, S.I. \& Sasai, Y.(2000). Induction of midbrain dopaminergic neurons from ES cells by stromal cell-derived inducing activity. Neuron., Vol.28, No.1, (Oct 2000) pp.31-40, ISSN

Kim, D.S.; Kim, J.Y.; Kang, M.; Cho, M.S. \& Kim, D.W. (2007).Derivation of functional dopamine neurons from embryonic stem cells. Cell Transplant., Vol.16, No. 2, (2007) pp.117-123,ISSN

Kim, J.H.; Auerbach, J.M.; Rodriguez-Gomez, J.A.; Velasco, I.; Gavin, D.; Lumelsky, N.; Lee, S.H.; Nguyen, J.; Sanchez-Pernaute, R.; Bankiewicz, K. \& McKay, R. (2002). Dopamine neurons derived from embryonic stem cells function in an animal model of Parkinson's disease. Nature., Vol.418, No.6893 ,(Jul 2002) pp.50-56, ISSN

Kim, J.Y.; Koh, H.C.; Lee, J.Y.; Chang, M.Y.; Kim, Y.C.; Chung, H.Y.; Son, H.; Lee, Y.S.; Studer, L.; McKay, R. \& Lee, S.H. (2003). Dopaminergic neuronal differentiation from rat embryonic neural precursors by Nurr1 overexpression. J Neurochem., Vol.85, No.6, (Jun 2003) pp.1443-1454, ISSN 
Kim, M.; Lee, S.T.; Chu, K. \& Kim, S.U. (2008).Stem cell-based cell therapy for Huntington disease: a review. Neuropathology.,Vol.28,No.1,(Feb 2008)pp.1-9,ISSN

Kim, M.; Habiba, A.; Doherty, J.M.; Mills, J.C.; Mercer, R.W. \& Huettner, J.E.(2009). Regulation of mouse embryonic stem cell neural differentiation by retinoic acid. Dev Biol., Vol.328, No.2, (Apr 2010) pp.456-471,ISSN

Kim, S.U. \& de Vellis, J.(2009).Stem Cell-Based Cell Therapy in Neurological Diseases: A Review. J Neurosci. Res., Vol.87,No.10,(Aug2009)pp.2183-2200,ISSN

Kim, T.E.; Lee, H.S.; Lee, Y.B.; Hong, S.H.; Lee, Y.S.; Ichinose, H.; Kim, S.U. \& Lee, M.A.(2003). Sonic hedgehog and FGF8 collaborate to induce dopaminergic phenotypes in the Nurr1-overexpressing neural stem cell. Biochem Biophys Res Commun., Vol.305, No.4, (Jun 2003) pp.1040-1048, ISSN

Kish, S.J.; Shannak, K. \& Hornykiewitcz, O.(1988). Uneven pattern of dopamine loss in the striatum of patients with idiopathic Parkinson's disease.Pathophysiologic and clinical implications. N Engl J Med., Vol.318, No.14, (Apr 1988) pp.876-880, ISSN

Kleppner, S.R.; Robinson, K.A.; Trojanowski, J.Q. \& Lee, V.M.(1995). Transplanted human neurons derived from a teratocarcinoma cell line (NTera-2) mature, integrate, and survive for over 1 year in the nude mouse brain. J Comp Neurol., Vol.357, No.4, (Jul 1995) pp.618-632, ISSN

Kordower, J.H.; Goetz, C.G.;Freeman, T.B. \& Olanow, C.W.(1997). Doparminergic transplants in patients with Parkinson's disease: neuroanatomical correlates of clinical recovery.Exp Neurol., Vol.144, No.1, (Mar 1997) pp.41-46, ISSN

Kwak, Y.D.; Dantuma, E.; Merchant, S.; Bushnev, S. \& Sugaya K. (2010). Amyloid-beta Precursor Protein Induces Glial Differentiation of Neural Progenitor Cells by Activation of the IL-6/gp130 Signaling Pathway. Neurotox Res., [Epub ahead of print](Mar 2010),ISSN

Lang, A.E. \& Lozano, A.M. (1998a). Parkinson's disease. First of two parts. N Engl J Med., Vol.339, No.15, (Oct 1998) pp. 1044-1053, ISSN

Lang, A.E. \& Lozano, A.M.(1998b). Parkinson's disease. Second of two parts. N Engl J Med., Vol.339, No.16, (Oct 1998) pp.1130-1143, ISSN

Lee, S.H.; Lumelsky, N.; Studer, L.; Auerbach, J.M. \& McKay, R.D.(2000). Efficient generation of midbrain and hindbrain neurons from mouse embryonic stem cells. Nat Biotechnol., Vol.18,NO.6, (Jun 2000)pp.675-9,ISSN

Leegwater-Kim, J. \& Cha, J.H.(2004).The paradigm of Huntington's disease: therapeutic opportunities in neurodegeneration. NeuroRx., Vol.1, No. 1,( Jan 2004)pp.128138,ISSN

Lendahl, U.; Zimmerman, L.B. \& McKay, R.D.(1990). CNS stem cells express a new class of intermediate filament protein. Cell., Vol.60, No.4, (Feb 1990)pp. 585- 595,ISSN

Li, D.; Tang, J.; Xu, H.; Fan, X.; Bai, Y.\& Yang, L.(2008).Decreased hippocampal cell proliferation correlates with increased expression of BMP4 in the APPswe/PS1DeltaE9 mouse model of Alzheimer's disease. Hippocampus,Vol. 18,No. 7, (April 2008) pp.692-698. ISSN

Li, X.J.; Du, Z.W.; Zarnowska, E.D.; Pankratz, M.; Hansen, L.O.; Pearce, R.A. \& Zhang, S.C.(2005). Specification of motoneurons from human embryonic stem cells. Nat Biotechnol., Vol.23, No.2, (Feb 2005) pp.215-221,ISSN

Li, X.J.; Hu, B.Y.; Jones, S.A.; Zhang, Y.S.; Lavaute, T.; Du, Z.W. \& Zhang, S.C.(2008). Directed differentiation of ventral spinal progenitors and motor neurons from 
human embryonic stem cells by small molecules. Stem Cells., Vol.26, No.4, (Jan 2008) pp.886-893,ISSN

Li, Y.; Powell, S.; Brunette, E.; Lebkowski, J. \& Mandalam, R.(2005). Expansion of human embryonic stem cells in defined serum-free medium devoid of animal-derived products. Biotechnol Bioeng., Vol. 91, No.6, (Sep 2005) pp. 688-698,ISSN

Li, Z.; Gao, C.; Huang, H.; Sun, W.; Yi, H.; Fan, X. \& Xu, H. (2010). Neurotranmitter phynotype differentiation and synapse formation of neural precursors engrafting in Abeta (1-40) injured rats hippocampus. J Alzheimers Dis., [Epub ahead of print ] (Aug 2010),ISSN

Liber, D.; Domaschenz, R.; Holmqvist, P.H.; Mazzarella, L.; Georgiou, A.; Leleu, M.; Fisher, A.G.; Labosky, P.A. \& Dillon, N.(2010) .Epigenetic priming of a pre-B cell-specific enhancer through binding of Sox 2 and Foxd3 at the ESC stage. Cell Stem Cell., Vol. 7, No. 1, ( Jul 2010) pp.114-126, ISSN

Lindvall, O.; Brundin, P.; Widner, H.; Rehncrona, S.; Gustavii, B.; Frackowiak, R.; Leenders, K.L.; Sawle, G.; Rothwell, J.C.; Marsden, C.D.; et al. (1990). Grafts of fetal dopamine neurons survive and improve motor function in Parkinson's disease. Science., Vol.247, No.4942, (Feb 1990) pp.574-577, ISSN

Lindvall, O.; Rehncrona, S.; Brundin, P.; Gustavii, B.; Astedt, B.; Widner, H.; Lindholm, T.; Björklund, A.; Leenders, K.L.; Rothwell, J.C.; Frackowiak, R.; Marsden, D.; Johnels, B.; Steg, G.; Freedman, R.; Hoffer, B.J.; Seiger, A.; Bygdeman, M.; Strömberg, I. \& Olson, L.(1989). Human fetal dopamine neurons grafted into the striatum in two patients with severe Parkinson's disease: A detailed account of methodology and a 6-month follow-up. Arch Neurol., Vol.46, No.6, (Jun 1989) pp.615-631, ISSN

Ling, Z.D.; Potter, E.D.; Lipton, J.W. \& Carvey, P.M. (1998). Differentiation of mesencephalic progenitor cells into dopaminergic neurons by cytokines. Exp Neurol., Vol.149, No.2, (Feb 1998) pp.411-423, ISSN

López-González, R.; Kunckles, P. \& Velasco, I.(2009). Transient recovery in a rat model of familial amyotrophic lateral sclerosis after transplantation of motor neurons derived from mouse embryonic stem cells. Cell Transplant., Vol.18, No.10, (Aug 2009)pp.1171-1181,ISSN

Luo, Y.; Kuang, S.Y. \& Hoffer, B. (2009). How useful are stem cells in PD therapy? Parkinsonism Relat Disord., Vol.15,No. Suppl 3, (2009 Dec) pp. S171-175,ISSN

Mangialasche, F.; Solomon, A.; Winblad, B.; Mecocci, P.; Kivipelto, M. \& Mangialasche, F. (2010). Alzheimer's disease: clinical trials and drug development. Lancet Neurol. ,Vol.9, No.7, (Jul 2010) pp.702-716, ISSN

Marchetto, M.C.; Muotri, A.R.; Mu, Y.; Smith, A.M.; Cezar, G.G. \& Gage, F.H.(2008). Noncell-autonomous effect of human SOD1 G37R astrocytes on motor neurons derived from human embryonic stem cells. Cell Stem Cell., Vol.3, No.6, (Dec 2008) pp.649657,ISSN

Marlatt, M.W. \& Lucassen, P.J.(2010). Neurogenesis and Alzheimer's disease: Biology and pathophysiology in mice and men. Curr Alzheimer Res., Vol.7,No.2,(Mar 2010)pp.113-125,ISSN

Maroof, A.M.; Brown, K.; Shi, S.H.; Studer, L. \& Anderson, S.A. (2010). Prospective isolation of cortical interneuron precursors from mouse embryonic stem cells. $J$ Neurosci.,Vol.30,No.13, (Mar 2010) pp. 4667-4675,ISSN 
Martin,G.R.; Silver, L.M.; Fox, H.S.\& Joyner, A.L. (1987). Establishment of embryonic stem cell lines from preimplantation mouse embryos homozygous for lethal mutations in the t-complex. Dev Biol., Vol. 121, No. 1, (May 1987), pp.20-28,ISSN

Marutle, A.; Ohmitsu, M.; Nilbratt, M.; Greig, N.H.; Nordberg, A. \& Sugaya, K. (2007). Modulation of human neural stem cell differentiation in Alzheimer (APP23) transgenic mice by phenserine. Proc Natl Acad Sci U S A., Vol.104,NO.30, (Jul 2007)pp.12506-12511,ISSN

McKay,B.S.; Goodman, B. ; Falk, T. \& Sherman, S.J.(2006). Retinal pigment epithelial cell transplantation could provide trophic support in Parkinson's disease: results from an in vitro model system. Exp Neurol., Vol.201, No.1, (Jun 2006) pp.234-243, ISSN

Melone, M.A. \& Jori, F.P.(2005) .Peluso G.Huntington's disease: new frontiers for molecular and cell therapy. Curr Drug Targets.,Vol.6,No. 1, (Feb 2005) pp. 43-56,ISSN

Mitrecić, D.; Nicaise, C.; Gajović, S. \& Pochet, R.(2010). Distribution, differentiation, and survival of intravenously administered neural stem cells in a rat model of amyotrophic lateral sclerosis. Cell Transplant., Vol.19, No.5, (Mar 2010) pp.537548 ,ISSN

Miyazono, M.; Lee, V.M. \& Trojanowski, J.Q.(1995). Proliferation, cell death, and neuronal differentiation in transplanted human embryonal carcinoma (NTera2) cells depend on the graft site in nude and severe combined immunodeficient mice. Lab Invest., Vol.73, No.2, (Aug 1995) pp.273-283, ISSN

Moghadam, F.H.; Alaie, H.; Karbalaie, K.; Tanhaei, S.; Nasr Esfahani, M.H. \& Baharvand, H.; Transplantation of primed or unprimed mouse embryonic stem cell-derived neural precursor cells improves cognitive function in Alzheimerian rats. Differentiation., Vol.78, No.2-3, (Sep-Oct 2009) pp. 59-68,ISSN

Mohapel, P.; Mundt-Petersen, K.; Brundin, P. \& Frielingsdorf, H.(2006). Working memory training decreases hippocampal neurogenesis. Neuroscience., Vol. 142,NO.3, (Oct 2006)pp.609-613,ISSN

Morassutti, D.J.; Staines, W.A.; Magnuson, D.S.; Marshall, K.C.\& McBurney, M.W.(1994). Murine embryonal carcinoma-derived neurons survive and mature following transplantation into adult rat striatum. Neuroscience., Vol.58, No.4, (Feb 1994) pp.753-763, ISSN

Murry, C.E. \& Keller, G.,(2008). Differentiation of embryonic stem cells to clinically relevant populations: lessons from embryonic development. Cell., Vol. 132, No.4,(Feb 2008) pp. 661-680,ISSN

Nagai, M.; Re, D.B.; Nagata, T.; Chalazonitis, A.; Jessell, T.M.; Wichterle, H. \& Przedborski, S.(2007). Astrocytes expressing ALS-linked mutated SOD1 release factors selectively toxic to motor neurons. Nat Neurosci., Vol.10, No.5, (Apr 2007) pp.615622,ISSN

Nishimura, F.; Yoshikawa, M.; Kanda, S.;Nonaka, M.;Yokota, H.; Shiroi, A.;Nakase, H.; Hirabayashi, H.; Ouji, Y.; Birumachi, J.; Ishizaka, S. \& Sakaki, T. (2003). Potential use of embryonic stem cells for the treatment of mouse parkinsonian models: improved behavior by transplantation of in vitro differentiated dopaminergic neurons from embryonic stem cells. Stem Cells., Vol. 21, No. 2, (2003) pp.171-180, ISSN

Nishimura, A.L.; Mitne-Neto, M.; Silva, H.C.; Richieri-Costa, A.; Middleton, S.; Cascio, D.; Kok, F.; Oliveira, J.R.; Gillingwater, T.; Webb, J.; Skehel, P. \& Zatz, M.(2004). A 
mutation in the vesicle-trafficking protein VAPB causes late-onset spinal muscular atrophy and amyotrophic lateral sclerosis. Am J Hum Genet., Vol.75,No.5, (Sep 2004) pp.822-831, ISSN

Nizzardo, M.; Simone, C.; Falcone, M.; Locatelli, F.; Riboldi, G.; Comi, G.P. \& Corti, S.(2010). Human motor neuron generation from embryonic stem cells and induced pluripotent stem cells. Cell Mol Life Sci., [Epub ahead of print] (Jul 2010),ISSN

Ohtsuka, S. \& Dalton, S. (2008). Molecular and biological properties of pluripotent embryonic stem cells. Gene Ther., Vol.15, No.2,(Jan 2008) pp. 74-81,ISSN

Okabe, S.; Forsberg-Nilssona, K.; Cyril Spiro, A.; Segal, M. \& McKay, R.D.G. (1996). Development of neuronal precursor cells and functional postmitotic neurons from embryonic stem cells in vitro. Mech Dev. ,Vol.59, No. 1, (Sep 1996) pp. 89-102,ISSN

Okano, H. (2002). Neural stem cells: progression of basic research and perspective for clinical application. Keio J Med., Vol.51, No.3, (Sep 2002) pp.115-128,ISSN

O'Keeffe, F.E.; Scott, S.A.; Tyers, P.; O'Keeffe, G.W.; Dalley, J.W.; Zufferey, R. \& Caldwell, M.A. (2008). Induction of A9 dopaminergic neurons from neural stem cells improves motor function in an animal model of Parkinson's disease. Brain., Vol.131, No.3, (Mar 2008) pp.630-641, ISSN

Olanow, C.W.; Kordower, J. \& Freeman, T. (1996). Fetal nigral transplantation as a therapy for Parkinson's disease. Trends in Neurosciences., Vol.19, No.3, (Mar 1996) pp. 102109, ISSN

Oliveira, AA. Jr. \& Hodges, HM.(2005). Alzheimer's disease and neural transplantation as prospective cell therapy. Curr Alzheimer Res. ,Vol.2, No.1, (Jan 2005) pp.79-95, ISSN

Pera, M.F.; Andrade, J.; Houssami, S.; Reubinoff, B.; Trounson, A.; Stanley, E.G.;Ward-van Oostwaard, D.\& Mummery, C. (2004).Regulation of human embryonic stem cell differentiation by BMP-2 and its antagonist noggin. J Cell Sci., Vol.117, No.7, (Mar 2004)pp. 1269-1280,ISSN

Perlow, M.J.; Freed, W.J.; Hoffer, B.J.; Seiger, A.; Olson, L. \& Wyatt, R.J.(1979). Brain grafts reduce motor abnormalities produced by destruction of nigrostriatal dopamine system. Science., Vol.204, No.4393, (May 1979)pp.643-647, ISSN

Perry, J.J.; Shin, D.S. \& Tainer, J.A. (2010).Amyotrophic lateral sclerosis. Adv Exp Med Biol., Vol.685,(2010) pp.9-20, ISSN

Piccini, P.; Brooks, D.J.; Björklund, A.; Gunn, R.N.; Grasby, P.M.; Rimoldi, O.; Brundin, P.; Hagell, P.; Rehncrona, S.; Widner, H. \& Lindvall, O.(1999).Dopamine release from nigral transplants visualized in vivo in a Parkinson's patient. Nat Neurosci., Vol.2, No.12, (Dec 1999) pp.1137-1140, ISSN

Porayette, P.; Gallego, M.J.; Kaltcheva, M.M.; Bowen, R.L.; Vadakkadath Meethal, S. \& Atwood, C.S. (2009).Differential processing of amyloid-beta precursor protein directs human embryonic stem cell proliferation and differentiation into neuronal precursor cells. J Biol Chem.,Vol.284,NO.35, (Aug 2009)pp.23806-23817,ISSN

Potter, E.D.; Ling, Z.D. \& Carvey, P.M.(1999). Cytokine-induced conversion of mesencephalic-derived progenitor cells into dopamine neurons. Cell Tissue Res., Vol.296, No. 2, (May 1999) pp.235-246, ISSN

Rao, M.(2007).Tumorigenesis and embryonic stem cell-derived therapy.Stem Cells Dev.Vol.16, No.6,(Dec 2007) pp.903-904. ISSN 
Reubinoff, B.E.; Itsykson, P.;Turetsky, T.; Pera, M.F.; Reinhartz, E.; Itzik, A. \& Ben-Hur, T. (2001). Neural progenitors from human embryonic stem cells. Nat Biotechnol.,Vol.19,No. 12, (Dec 2001) pp. 1134-1140, ISSN

Revazova, E.S.; Turovets, N.A.; Kochetkova, O.D.; Agapova, L.S.; Sebastian, J.L.; Pryzhkova, M.V.; Smolnikova, V.I.; Kuzmichev, L.N. \& Janus, J.D.(2008). HLA homozygous stem cell lines derived from human parthenogenetic blastocysts. Cloning Stem Cell., Vol.10, No. 1, (Mar 2008) pp. 11-24,ISSN

Reyes, A.E.; Chacón, M.A.; Dinamarca, M.C.; Cerpa, W.; Morgan, C. \& Inestrosa, N.C. (2004). Acetylcholinesterase-Abeta complexes are more toxic than Abeta fibrils in rat hippocampus: effect on rat beta-amyloid aggregation, laminin expression, reactive astrocytosis, and neuronal cell loss. Am. J. Pathol., Vol.164, No.6,( Jun 2004) pp.2163-2174,ISSN

Ringdén, O.; Le Blanc, K. \& Hovatta, O. (2003). Transplantation of embryonic stem cells: possibilities and challenges. Transplantatio., Vol.76, No.7, (Oct 2003) pp.1011-1012, ISSN

Rizvanov, A.A.; Kiyasov, A.P.; Gaziziov, I.M.; Yilmaz, T.S.; Kaligin, M.S.; Andreeva, D.I.; Shafigullina, A.K.; Guseva, D.S.; Kiselev, S.L.; Matin, K.; Palotás, A.\& Islamov, R.R. (2008). Human umbilical cord blood cells transfected with VEGF and L(1)CAM do not differentiate into neurons but transform into vascular endothelial cells and secrete neuro-trophic factors to support neuro-genesis-a novel approach in stem cell therapy. Neurochem Int., Vol.53, No.6-8,( Dec 2008)pp. 389-394,ISSN

Rosen, D.R.; Siddique, T.; Patterson, D.; Figlewicz, D.A.; Sapp, P.; Hentati, A.; Donaldson, D.; Goto, J.; O'Regan, J.P. \& Deng, H.X. Mutations in $\mathrm{Cu} / \mathrm{Zn}$ superoxide dismutase gene are associated with familial amyotrophic lateral sclerosis. Nature., Vol.362,No.6415, (Mar 1993) pp.59-62,ISSN

Roze, E.; Bonnet, C.; Betuing, S. \& Caboche, J. (2010). Huntington's disease. Adv Exp Med.Biol., Vol. 685, (2010)pp.45-63,ISSN

Sakaguchi, D.S.; Van Hoffelen, S.J.; Grozdanic, S.D.; Kwon, Y.H.; Kardon, R.H.\& Young, M.J. (2005). Neural progenitor cell transplants into the developing and mature central nervous system. Ann N Y Acad Sci., Vol. 1049,(2005 May)pp.118-34,ISSN

Sauerzweig, S.; Munsch, T.; Lessmann, V.; Reymann, K.G. \& Braun, H.(2009). A population of serum deprivation-induced bone marrow stem cells (SD-BMSC) expresses marker typical for embryonic and neural stem cells. Exp Cell Res., Vol. 315,No.1,( Jan 2009) pp.50-66,ISSN

Schwarz, S.C. \& Schwarz, J.(2010).Translation of stem cell therapy for neurological diseases.Transl. Res., Vol. 156, No. 3, (Sep 2010)pp. 155-160,ISSN

Shihabuddin, L.S. \& Aubert, I. (2010). Stem cell transplantation for neurometabolic and neurodegenerative diseases. Neuropharmacology ., Vol.58, No. 6, (May 2010) pp. 845854, ISSN

Soares, S. \& Sotelo,C. (2004).Adult neural stem cells from the mouse subventricular zone are limited in migratory ability compared to progenitor cells of similar origin. Neuroscience Vol. 128, No. 4 , (2004) pp.807-817, ISSN

Song, J.; Lee, S.T.; Kang, W.; Park, J.E.; Chu, K.; Lee, S.E.; Hwang, T.; Chung, H. \& Kim, M.(2007).Human embryonic stem cell-derived neural precursor transplants attenuate apomorphine-induced rotational behavior in rats with unilateral quinolinic acid lesions. Neurosci Lett., Vol.423,No.1,(Aug 2007)pp.58-61,ISSN 
Song, S. \& Sanchez-Ramos, J. (2008). Preparation of neural progenitors from bone marrow and umbilical cord blood, In: Methods in molecular biology., John M Walker (Ed.), pp.123-134, Springerlink, ISBN, Clifton, N J

Soundararajan, P.; Lindsey, B.W.; Leopold, C. \& Rafuse, V.F.(2007). Easy and rapid differentiation of embryonic stem cells into functional motoneurons using sonic hedgehog-producing cells. Stem Cells., Vol.25, No.7, (Mar 2007)pp.1697-1706,ISSN

Srivastava, A.S.; Malhotra, R.; Sharp. J \& Berggren, T. (2008). Potentials of ES cell therapy in neurodegenerative diseases. Curr Pharm Des., Vol.14, No.36, (2008) pp.3873-3879, ISSN

Stewart, R.; Stojkovic, M. \& Lako, M. (2006). Mechanisms of self-renewal in human embryonic stem cells. Eur J Cancer.,Vol.42,No.9,(Jun 2006) pp.1257-1272,ISSN

Storch, A.; Paul, G.; Csete, M.; Boehm, B.O.; Carvey, P.M.; Kupsch, A. \& Schwarz, J. (2001).Long-term proliferation and dopaminergic differentiation of human mesencephalic neural precursor cells. Exp Neurol., Vol.170, No.2, (Aug 2001) pp.317-325, ISSN

Sugaya, K. \& Brannen, C.L.(2001). Stem cell strategies for neuroreplacement therapy in Alzheimer's disease. Med Hypotheses., Vol.57,No.6, ( Dec 2001)pp.697-700,ISSN

Sugaya, K. (2005). Possible use of autologous stem cell therapies for Alzheimer's disease. Curr Alzheimer Res., Vol.2,No.3,(Jul 2001)pp. 367-376,ISSN

Sugaya, K.; Alvarez, A.; Marutle, A.; Kwak, Y.D. \& Choumkina, E. (2006). Stem cell strategies for Alzheimer's disease therapy. Panminerva Med., Vol.48,No.2,(Jun 2006)pp. 87-96,ISSN

Sugaya, K. \& Merchant S. (2008). How to approach Alzheimer's disease therapy using stem cell technologies. J Alzheimers Dis., Vol.15, No.2,(Oct 2008) pp. 241-254,ISSN

Sugaya, K.; Kwak, Y.D.; Ohmitsu, O.; Marutle, A.; Greig, NH. \& Choumrina, E. (2007). Practical issues in stem cell therapy for Alzheimer's disease. Curr Alzheimer Res., Vol.4, No.4, (Sep 2007) pp. 370-377,ISSN

Takagi,Y.; Nishimura, M.; Morizane, A.; Takahashi, J.; Nozaki, K.; Hayashi, J.\& Hashimoto, N. (2005). Survival and differentiation of neural progenitor cells derived from embryonic stem cells and transplanted into ischemic brain. J Neurosurg., Vol.103,No. 2,(Aug 2005) pp.304-310,ISSN

Takahashi, K. \& Yamanaka, S. (2006). Induction of pluripotent stem cells from mouse e mbryonic and adult fibroblast cultures by defined factors. Cell., Vol.126, No.4,(Aug 2006) pp. 663-676,ISSN

Tang, J. ; Xu, H.W. ; Fan, X.T. ; Li, Z.F. ;Li, D.B. ; Yang, L. \& Zhou, G.J. (2007). Targeted migration and differentiation of engrafted neural precursor cells in amyloid betatreated hippocampus in rats. Neurosci Bull., Vol.23, No.5,(Sep 2007)pp. 263-270,ISSN

Tang, J.; Xu, H.; Fan, X.; Li, D.; Rancourt, D.; Zhou, G.; Li, Z. \& Yang, L.(2008). Embryonic stem cell-derived neural precursor cells improve memory dysfunction in Abeta(140) injured rats. Neurosci Res., Vol.62, No.2, (Oct 2008) pp.86-96,ISSN

Taupin, P. (2009). Adult neurogenesis, neural stem cells and Alzheimer's disease: developments, limitations, problems and promises. Curr. Alzheimer. Res., Vol.6,No.6, (Dec 2009) pp. 461-470, ISSN

Thomson, J.A.; Itskovitz-Eldor, J.; Shapiro, S.S.; Waknitz, M.A.; Swiergiel, J.J.; Marshall, V.S.\& Jones, J.M. (1998). Embryonic stem cell lines derived from human blastocysts. Science., Vol.282, No.5391, (Nov 1998) pp.1145-1147,ISSN 
Thonhoff, J.R.; Ojeda, L., \& Wu, P.(2009). Stem cell-derived motor neurons: applications and challenges in amyotrophic lateral sclerosis. Curr Stem Cell Res Ther., Vol.4, No.3, (Sep 2009) pp. 178-199, ISSN

Tropepe, V. (2007). Kinship and Descent: Redefining the Stem Cell Compartment in the Adult Hippocampus. Cell stem cell., Vol.1,No.5, (Nov 2007) pp. 481-483,ISSN

van Marum, R.J. (2008). Current and future therapy in Alzheimer's disease. Fundam Clin Pharmacol., Vol.22, No.3, (Jun 2008)pp.265-274, ISSN

Vandenbosch, R.; Borgs. L.; Beukelaers, P.; Belachew, S.; Moonen, G.; Nguyen, L. \& Malgrange , B. (2009). Adult neurogenesis and the diseased brain. Curr Med Chem., Vol.16,No.6,(2009) pp. 652-666, ISSN

Vazey, E.M.; Chen, K.; Hughes, S.M. \& Connor, B.(2006). Transplanted adult neural progenitor cells survive, differentiate and reduce motor function impairment in a rodent model of Huntington's disease. Exp Neurol., Vol.199,No.2,(2006)pp.384396,ISSN

Vazey, E.M.; Dottori, M.; Jamshidi, P.; Tomas, D.; Pera, M.F.; Horne, M. \& Connor, B.(2010). Comparison of Transplant Efficiency Between Spontaneously-Derived and NogginPrimed Human Embryonic Stem Cell Neural Precursors in the Quinolinic Acid Rat Model of Huntington's Disease. Cell Transplant., (Mar 2010). ISSN

Walker, F.O.(2007). Huntington's disease. Lancet., Vol.369, No. 9557, (Jan 2007) pp. 218228,ISSN

Walter, B.L. \& Vitek, J.L.(2004).Surgical treatment for Parkinson's disease. The Lancet Neurology., Vol.3, No. 12, (Dec 2004) pp.719-728, ISSN

Wang, Q.; Matsumoto, Y.; Shindo, T.; Miyake, K.; Shindo, A.; Kawanishi, M.; Kawai, N.; Tamiya, T. \& Nagao, S. (2006). Neural stem cells transplantation in cortex in a mouse model of Alzheimer's disease. J Med Invest. , Vol.53, No.1-2, (Feb 2006) pp.61-69, ISSN

Wernig, M.; Benninger, F.; Schmandt, T.; Rade, M.; Tucker, K.L.; Büssow, H.; Beck, H. \& Brüstle, O. (2004). Functional integration of embryonic stem cell-derived neurons in vivo. J Neurosci Vol.24,No. 22, (Jun 2004)pp.5258-5268.ISSN

Wernig, M.; Zhao, J. P.; Pruszak, J.; Hedlund, E.; Fu, D.; Soldner, F.; Broccoli, V.; Constantine-Paton, M.; Isacson, O. \& Jaenisch, R. (2008). Neurons derived from reprogrammed fibroblasts functionally integrate into the fetal brain and improve symptoms of rats with Parkinson's disease. Proc Natl Acad Sci U S A., Vol.105, No.15, (Apr 2008) pp.5856 -5861, ISSN

Wessel Schmidt, R.L.(2007).Generation of Human embryonic stem cell-derived teratomas, In: Human Stem Cell Manual. A Laboratory Guide., Jeanne Loring (Ed.), pp.162170,Academic Press. ISBN, La Jolla, California

Weydt, P.; Yuen, E.C.; Ransom, B.R. \& Möller, T.(2004). Increased cytotoxic potential of microglia from ALS-transgenic mice. Glia., Vol.48, No.2, (Nov 2004) pp.179182,ISSN

Wichterle, H. \& Peljto, M.(2008). Differentiation of mouse embryonic stem cells to spinal motor neurons. In: Curr Protoc Stem Cell Bio, Andrew Elefanty (Ed.),pp. Chapter 1:Unit 1H.1.1-1H.1.9,ISSN

Winkler, C.; Kirik, D. \& Björklund, A.(2005).Cell transplantation in Parkinson's disease: how can we make it work?. Trends in Neurosciences., Vol.28, No.2, (Feb 2005) pp.86-92, ISSN 
Whitehouse, P.J.; Price, D.L.; Clark, A.W.; Coyle, J.T. \& DeLong, M.R. (1981).Alzheimer disease: evidence for selective loss of cholinergic neurons in the nucleus basalis. Ann Neurol., Vol.10,No.2,(Aug 1981)pp.122-126,ISSN

Wojcik, B.E.; Nothias, F.; Lazar, M.; Jouin, H.; Nicolas, J. \& Peschanski, M.; (1993).Catecholaminergic neurons result from the intracerebral implantation of embryonal carcinoma cells. Proc Natl Acad Sci U S A., Vol.90, No.4, (Feb 1993) pp.1305-1309, ISSN

Wurst, W. \& Bally-Cuif, L.(2001). Neural plate patterning: upstream and downstream of the isthmicorganizer. Nat Rev Neurosci., Vol.2, No.2, (Feb 2001) pp.99-108 , ISSN

Xu, H.; Fan, X.; Tang, J.; Zhou, G.; Yang, L.; Wu, X.; Liu, S.; Qu, J. \&Yang, H. (2005). A modified method for generation of neural precursor cells from cultured mouse embryonic stem cells. Brain Res Brain Res Protoc.,Vol.15,No.1,(May 2005)pp.5258 ,ISSN

Xu, H.; Fan, X.; Wu, X.; Tang, J. \& Yang, H.(2005). Neural precursor cells differentiated from mouse embryonic stem cells relieve symptomatic motor behavior in a rat model of Parkinson's disease. Biochem Biophys Res Commun., Vol. 326, No.1 ,(Jan 2005) pp.115-122,ISSN

Xu, L.; Yan, J.; Chen, D.; Welsh, A.M.; Hazel, T.; Johe, K.; Hatfield, G. \& Koliatsos, V.E.(2006). Human neural stem cell grafts ameliorate motor neuron disease in SOD1 transgenic rats. Transplantation., Vol. 82, No.7, (Oct 2006) pp.865-875,ISSN

Xu, R.H.; Sampsell-Barron, T.L.;Gu, F., Root, S.; Peck, R.M.; Pan, G.;Yu. J.; AntosiewiczBourget, J.; Tian, S.; Stewart, R. \& Thomson, J.A. (2008). NANOG is a direct target of TGFbeta/activin-mediated SMAD signaling in human ESCs. Cell Stem Cell., Vol.3, No. 2, (Aug 2008)pp. 196-206,ISSN

Yang, Y.; Hentati, A.; Deng, H.X.; Dabbagh, O.; Sasaki, T.; Hirano, M.; Hung, W.Y.; Ouahchi, K.; Yan, J.; Azim, A.C.; Cole, N.; Gascon, G.; Yagmour, A.; Ben-Hamida, M.; Pericak-Vance, M.; Hentati, F. \& Siddique, T.(2001). The gene encoding alsin, a protein with three guanine-nucleotide exchange factor domains, is mutated in a form of recessive amyotrophic lateral sclerosis. Nat Genet., Vol.29,No.2, (Oct 2001) pp.160-165,ISSN

Ye, W.; Shimamura, K.; Rubenstein, J. L.; Hynes, M. A. \& Rosenthal, A.(1998) FGF and Shh signals control dopaminergic and serotonergic cell fate in the anterior neural plate. Cell., Vol.93, No.5, (May 1998) pp.755-766, ISSN

Yin, J.; Ma, Y.; Yin, Q.; Xu, H.; An, N.; Liu, S.; Fan, X. \& Yang H. (2007). Involvement of overexpressed BMP4 in pentylenetetrazol kindling-induced cell proliferation in the dentate gyrus of adult rats. Biochem Biophys Res Commun., Vol.355,No.1,(Mar 2007)pp.54-60,ISSN

Zhang, X. Q. \& Zhang, S. C.(2010). Differentiation of neural precursors and dopaminergic neurons from human embryonic stem cells. Methods Mol Biol., Vol.584, (2010)pp.355-366,ISSN

Zhang, K.; Li, L.; Huang, C.; Shen, C.; Tan, F.; Xia, C.; Liu, P.; Rossant, J.\& Jing, N. (2010). Distinct functions of BMP4 during different stages of mouse ES cell neural commitment. Development., Vol.137,NO.13, (Jul 2010)pp.2095-2105,ISSN

Zhao, C.; Deng, W. \& Gage, F.H.(2008). Mechanisms and functional implications of adult neurogenesis. Cell., Vol.132,NO.4, (Feb 2008)pp.645-660,ISSN 
Zhao, W.; Beers, D.R.; Henkel, J.S.; Zhang, W.; Urushitani, M.; Julien, J.P. \& Appel, S.H.(2010). Extracellular mutant SOD1 induces microglial-mediated motoneuron injury. Glia., Vol.58, No.2, (Jan 2010) pp.231-243,ISSN 


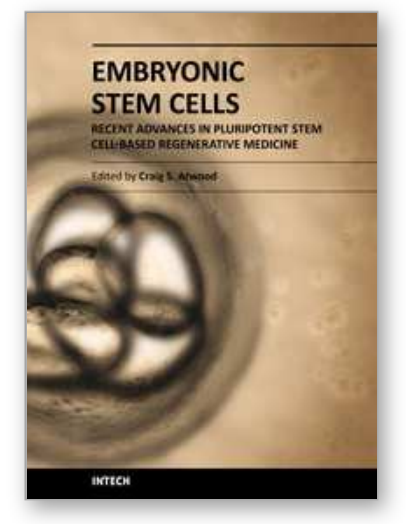

\section{Embryonic Stem Cells - Recent Advances in Pluripotent Stem Cell- Based Regenerative Medicine \\ Edited by Prof. Craig Atwood}

ISBN 978-953-307-198-5

Hard cover, 410 pages

Publisher InTech

Published online 26, April, 2011

Published in print edition April, 2011

Pluripotent stem cells have the potential to revolutionise medicine, providing treatment options for a wide range of diseases and conditions that currently lack therapies or cures. This book describes recent advances in the generation of tissue specific cell types for regenerative applications, as well as the obstacles that need to be overcome in order to recognize the potential of these cells.

\section{How to reference}

In order to correctly reference this scholarly work, feel free to copy and paste the following:

Xiaotang Fan, Yongping Tang, Kai Wang, Xiang Cui, Shiqi Tao and Haiwei Xu (2011). Embryonic Stem Cell in the Therapy of Neurodegenerative Diseases, Embryonic Stem Cells - Recent Advances in Pluripotent Stem Cell-Based Regenerative Medicine, Prof. Craig Atwood (Ed.), ISBN: 978-953-307-198-5, InTech, Available from: http://www.intechopen.com/books/embryonic-stem-cells-recent-advances-in-pluripotent-stem-cell-basedregenerative-medicine/embryonic-stem-cell-in-the-therapy-of-neurodegenerative-diseases

\section{INTECH}

open science | open minds

\author{
InTech Europe \\ University Campus STeP Ri \\ Slavka Krautzeka 83/A \\ 51000 Rijeka, Croatia \\ Phone: +385 (51) 770447 \\ Fax: +385 (51) 686166 \\ www.intechopen.com
}

\author{
InTech China \\ Unit 405, Office Block, Hotel Equatorial Shanghai \\ No.65, Yan An Road (West), Shanghai, 200040, China \\ 中国上海市延安西路65号上海国际贵都大饭店办公楼 405 单元 \\ Phone: +86-21-62489820 \\ Fax: $+86-21-62489821$
}


(C) 2011 The Author(s). Licensee IntechOpen. This chapter is distributed under the terms of the Creative Commons Attribution-NonCommercialShareAlike-3.0 License, which permits use, distribution and reproduction for non-commercial purposes, provided the original is properly cited and derivative works building on this content are distributed under the same license. 